OPEN ACCESS

Edited by:

Alexandros Tsoupras, University of Limerick, Ireland

Reviewed by:

Alex Kojo Anderson,

University of Georgia, United States Carla Ferreri,

National Research Council (CNR), Italy

*Correspondence:

Kazim Sahin

nsahinkm@yahoo.com

Specialty section

This article was submitted to

Nutritional Epidemiology,

a section of the journal

Frontiers in Nutrition

Received: 06 July 2020 Accepted: 10 September 2020 Published: 22 October 2020

Citation:

Sahin E, Orhan C, Uckun FM and Sahin K (2020) Clinical Impact Potential of Supplemental Nutrients as Adjuncts of Therapy in High-Risk COVID-19 for Obese Patients.

Front. Nutr. 7:580504.

doi: 10.3389/fnut.2020.580504

\section{Clinical Impact Potential of Supplemental Nutrients as Adjuncts of Therapy in High-Risk COVID-19 for Obese Patients}

\author{
Emre Sahin ${ }^{1}$, Cemal Orhan ${ }^{1}$, Fatih M. Uckun ${ }^{2,3}$ and Kazim Sahin ${ }^{1 *}$ \\ ${ }^{1}$ Department of Nutrition, School of Veterinary Medicine, Firat University, Elazig, Turkey, ${ }^{2}$ COVID-19 Task Force, Reven \\ Pharmaceuticals, Golden, CO, United States, ${ }^{3}$ Department of Developmental Therapeutics, Immunology and Integrative \\ Medicine, Ares Pharmaceuticals, St. Paul, MN, United States
}

The emergence of severe acute respiratory syndrome coronavirus 2 (SARS-CoV-2) disease (COVID-19) in China at the end of 2019 caused a major global pandemic and continues to be an unresolved global health crisis. The supportive care interventions for reducing the severity of symptoms along with participation in clinical trials of investigational treatments are the mainstay of COVID-19 management because there is no effective standard therapy for COVID-19. The comorbidity of COVID-19 rises in obese patients. Micronutrients may boost the host immunity against viral infections, including COVID-19. In this review, we discuss the clinical impact potential of supplemental nutrients as adjuncts of therapy in high-risk COVID-19 for obese patients.

Keywords: SARS-CoV-2, inflammation, cytokines, micronutrients, nutrition

\section{INTRODUCTION}

Severe acute respiratory syndrome coronavirus 2 (SARS-CoV-2) disease (COVID-19) has been declared a pandemic by the World Health Organization with more than 13.378 .800 million confirmed cases and more than 580.000 deaths worldwide (1). Immunocompromised risk groups of the populations have high mortality rates because of the insufficient host immunity $(2,3)$. SARS-CoV-2 damages the respiratory tract and causes acute lung injury (ALI) $(2,4,5)$. ALI triggers an inflammatory response while stimulating the immune system. This inflammatory immune response is associated with a cytokine storm that may result in a potentially fatal acute respiratory distress syndrome (ARDS) characterized by increased production of reactive oxygen species (ROS) as well as pro-inflammatory cytokines and chemokines (6). The cytokine storm may disrupt an effective anti-viral immune response and cause severe lymphocytopenia as well as T-cell exhaustion in affected COVID-19 patients $(7,8)$.

The nutritional status of the human body plays a pivotal role in developing an effective and appropriately balanced immune response to pathogenic viruses (9). Recent studies confirmed the importance of host nutritional status in surviving the COVID-19 challenge $(6,10,11)$. The protein-energy malnutrition (PEM) causes an imbalanced immune response to viral pathogens that can result in infiltration of the lungs by inflammatory cells and the development of pneumonitis following viral infection (12). The comorbidities of COVID-19 patients are correlated with the severity of PEM and contribute to a higher risk of ARDS and increased case mortality rate (13). In COVID-19, the decreased serum albumin (14) and prealbumin (15) levels have prognostic value. Low serum prealbumin levels serve as a surrogate marker for malnutrition and a poor 
prognostic factor (16). We believe that the nutritional status of all COVID-19 patients should be carefully evaluated, and consideration given to patient-tailored special diet programs that ensure an adequate and balanced intake of proteins, calories, and micronutrients (17). Adequate daily protein, especially whey and soy, intake have beneficial effects on the antioxidant defense system and host immunity (18). Among the various sources of protein, the whey protein has been recently recommended as a well-balanced and easy to digest amino acid and protein source with anabolic (19), anti-inflammatory (20), and immunomodulatory properties (21) as well as antiviral effects (22). Besides being an energy-rich part of the daily diet for balanced caloric intake, dietary fats, including fish oil and vegetable oils, provide a source for essential fatty acids as well as fat-soluble vitamins affecting metabolism and immunity. The essential fatty acid alpha-linolenic acid (ALA, 18:3n-3, omega-3), and the semi-essential fatty acids eicosapentaenoic acid (EPA), and docosahexaenoic acid (DHA) $(23,24)$, can be useful in supporting immune defense and the treatment of inflammatory diseases caused by both viruses and bacteria (25). In addition, essential micronutrients including vitamins and minerals, play an important role for the functional integrity and responsiveness of our immune system. Some of the vitamins (A, pyridoxine, cobalamin, folate, $\mathrm{C}, \mathrm{D}$, and $\mathrm{E}$ ) and trace minerals such as $\mathrm{Zn}$, $\mathrm{Cu}, \mathrm{Se}$, and Fe takes the crucial role to maintain and support the immune system (6). Balanced nutrition and intake of nutrients in appropriate amounts and composition may reduce the levels of pro-inflammatory cytokines and their side effects in COVID-19 patients (10).

Obesity has a rising prevalence, and it is considered a clinically significant risk factor for metabolic diseases as well as infections $(26,27)$. The consumption of "poor quality" foods often results in a nutritional deficiency in obese persons despite the higher than average amounts of food consumed (25). Such a nutritional deficiency may increase the severity of COVID-19 with increased morbidity and mortality (28). In this review, we discuss the possible role of micronutrients in the pathophysiology and survival outcome of COVID-19. We also review the current knowledge about the emerging role of supplemental nutrients as adjuncts to the supportive care for COVID-19, especially in obese patients.

\section{OBESITY AND COVID-19}

Obesity has detrimental effects on pulmonary function. Functional residual capacity and expiratory reserve volume are negatively affected by obesity as a consequence of the airway closure by fat accumulation in the mediastinal, thoracic, and abdominal cavity (29). Along with the rising body fat content, excessive secretion of adipokines, and cytokines from adipose tissue are thought to both compromises the immune system responsiveness to infections and cause systemic inflammation (27). The levels of free fatty acid (FFA), and lipopolysaccharide (LPS) released by gut bacteria increase during obesity which triggers activation of the (i) Toll-like receptor 4 (TLR4) pathway, (ii) adipose tissue macrophages (30) as well as (iii) nuclear factorkappa $\beta$ (NF-к $\beta$ ) pathway (31). M1 phenotype macrophages that initiate and regulate inflammatory reactions through interferon-gamma (IFN- $\gamma$ ), TLR4, LPS, and FFA stimulation become the primary immune system elements located in the adipose tissue (32). Many inflammatory cytokines such as tumor necrosis factor-alpha (TNF- $\alpha$ ), interleukin-1 $\beta$ (IL-1 $\beta$ ), IL-6, IL-12, and IL-18 are secreted by M1 macrophages. Therefore, T helper cell 1 (Th1) to Th2 ratio, (26) and Th17 increase in obesity, which results in an immune imbalance (33). M1 macrophages also play an essential role in the development of tissue-level insulin resistance in obesity. This is owing in part to the elevated levels of inflammatory factors that impair the c-Jun N-Terminal Protein Kinase 1 and Iк $\beta$ kinase/NF- $\kappa \beta$ cascades which regulate phosphorylation of insulin receptor substrates (IRS1 and IRS2) (34) (Figure 1). Besides the insulin resistance, the beta-cell function of the pancreas may be decreased during longterm obesity due to the continuous FFA exposure that activates the NF- $\kappa \beta$ signaling pathway (35). In addition, venous thromboembolism is encountered more frequently by obese individuals due to the prothrombotic effects of low-grade chronic inflammation (36-38). The prothrombotic effects of inflammation are triggered by platelet activation (39), increased activity of coagulant factors (factor VIIa, VIII, IX, X, fibrinogen, and von Willebrand factor), stimulation adhesion molecules (P-selectin), and downregulation of endogenous anticoagulant factors (antithrombin, and protein C) (40). In addition, the plasminogen activator inhibitor-1 (PAI-1), a prothrombotic adipokine, also contributes to augmented venous thromboembolism of obesity (41). Coagulopathy, including DIC, is one of the main causes of mortality in COVID-19 (42).

Because of the overlapping systemic inflammation of obesity and systemic inflammation triggered by viral sepsis in COVID-19, obese patients with COVID-19 experience greater severity of pulmonary and metabolic complications as well as multi-organ dysfunction (4345). Therefore, several micronutrients may have clinically meaningful beneficial effects in obese COVID-19 patients (46) (Figure 2). In COVID-19 patients many evidence demonstrates the metabolic link between inflammatory state and cytokine storm that mainly responsible for respiratory symptoms (45).

Several studies have shown a relationship between high BMI and severity of COVID-19. Ho et al. (47) reported that the risk of critical illness in COVID-19 increases by $44 \%$ for overweight people and almost doubles for obese patients. Likewise, an observational study using electronic health records indicated that obesity is an important contributing factor for case mortality in COVID-19 (48). Because obese patients have an impaired immune system, they may have inadequate cellular immune responses to pathogens and this acquired immunodeficiency increases their susceptibility to infections (49). In addition to the reduced T-effector cell function, the unbalanced production of immunomodulatory endocrine hormones also contribute to poor host immunity of obese persons against infections (50). Balanced nutrition and micronutrients help prevent the 


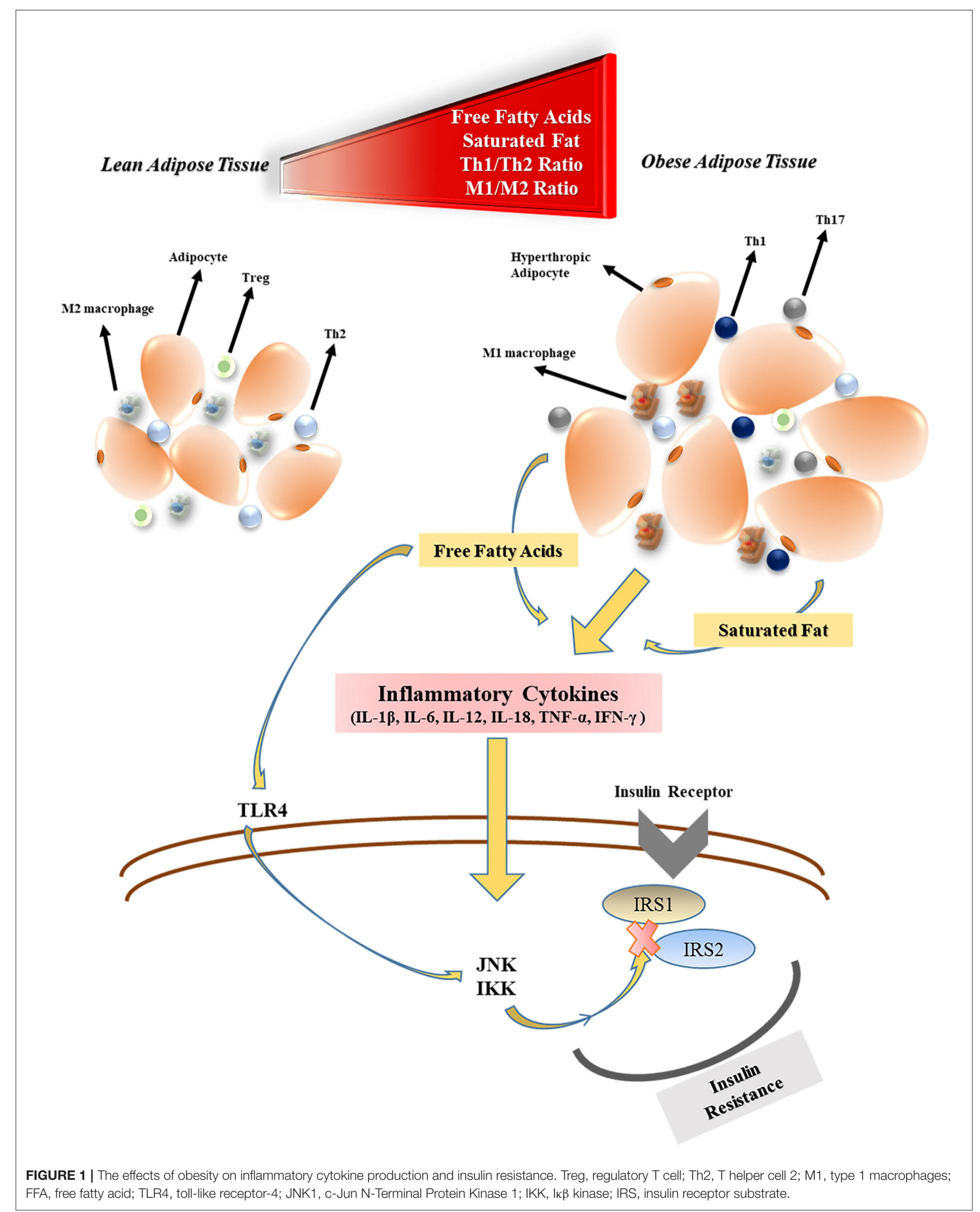




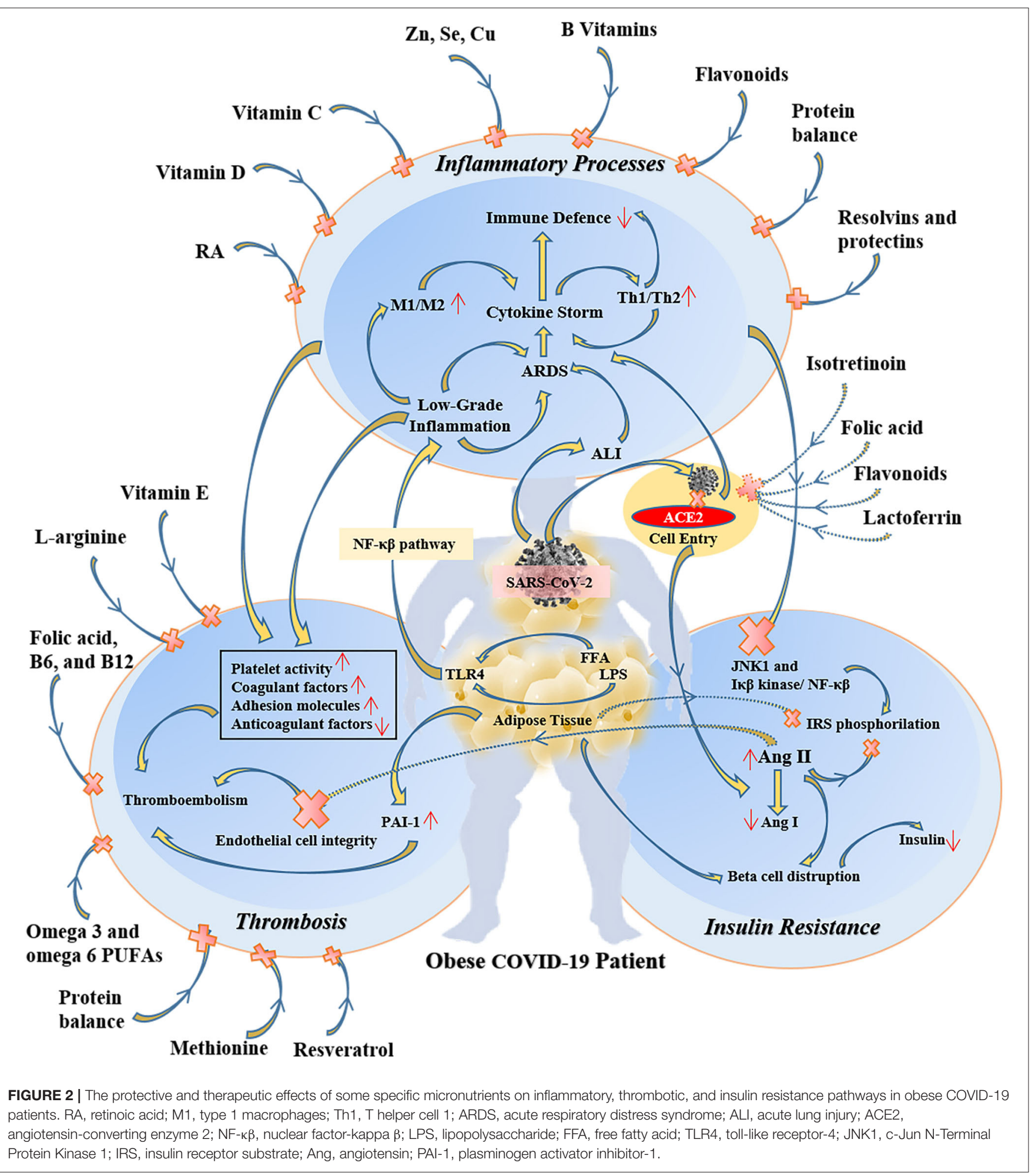

unfavorable outcomes observed in both obesity and COVID-19 (Table 1) (51-78).

The complex interplay between obesity and COVID-19 is explained by several mechanisms. SARS-CoV-2 uses the angiotensin-converting enzyme-2 (ACE2) for cell entry, and the amount of this transmembrane enzyme is found larger amounts in obese individuals (79). It is probably due to higher ACE2 expression in adipocytes of people with obesity (80). Therefore, adipose tissue of obese individuals can be a potential target for SARS-CoV-2 before spreading to other organs (81). Assuming 
TABLE 1 | The possible effects of some micronutrients on common symptoms of COVID-19 and obesity.

\begin{tabular}{|c|c|c|c|}
\hline Micronutrients & Key Mechanism of Action & Outcomes & References \\
\hline Vitamin A & $\begin{array}{l}\text { - Inhibition of M1 macrophage } \\
\text { - Downregulation of IFN- } \gamma \\
\text { - Promotion of Treg via inhibiting Th17 shifting } \\
\text { - Inhibition of ACE2 by isotretinoin } \\
\text { - Epithelial cell repairing properties }\end{array}$ & $\begin{array}{l}\text { - Inflammatory status } \downarrow \\
\text { - Probably insulin resistance } \downarrow \\
\text { - Probably viral replication } \downarrow \\
\text { - Lung damage prevention }\end{array}$ & $(51-55)$ \\
\hline Vitamin C & $\begin{array}{l}\text { - Protection of the respiratory system } \\
\text { - Promotion of antioxidation and anti-inflammation properties } \\
\text { - ROS scavenging activity } \\
\text { - Inhibition of NF-к } \beta \text { pathway }\end{array}$ & $\begin{array}{l}\text { - Inflammatory status } \downarrow \\
\text { - Immunity } \uparrow\end{array}$ & $(56)$ \\
\hline Vitamin D & $\begin{array}{l}\text { - Reduction of the risk of contracting respiratory infections } \\
\text { - Regulation of Th1/Th2 balance }\end{array}$ & Immunity $\uparrow$ & $(57)$ \\
\hline Vitamin E & $\begin{array}{l}\text { - ROS scavenging activity } \\
\text { - Inhibition of acute neutrophil inflammation in lung }\end{array}$ & $\begin{array}{l}\text { - Inflammatory status } \downarrow \\
\text { - Lung damage prevention }\end{array}$ & $(58,59)$ \\
\hline B vitamins & $\begin{array}{l}\text { - Protection the respiratory system } \\
\text { - Reduction of the risks of infection and re-infection } \\
\text { - Reduction of inflammatory cytokine production } \\
\text { - Regulation of the CD4/CD8 ratio and natural killer cell activity by } \\
\text { vitamin B12 } \\
\text { - Inhibition of ACE2 by folic acid } \\
\text { - Prevention of hyperhomocysteinemia by folic acid, B6, and B12 }\end{array}$ & $\begin{array}{l}\text { - Inflammatory status } \downarrow \\
\text { - Lung damage prevention } \\
\text { - Immunity } \uparrow \\
\text { - Probably insulin resistance } \downarrow \\
\text { - Probably viral replication } \downarrow \\
\text { - Prevents thromboembolism }\end{array}$ & $(60-64)$ \\
\hline Selenium & $\begin{array}{l}\text { - Antioxidative and anti-inflammatory properties in high-risk adults } \\
\text { - Regulation of M1/M2 macrophage } \\
\text { - Cofactor for glutathione peroxidase } \\
\text { - Oxidizing capacity } \\
\text { - Anticoagulant }\end{array}$ & $\begin{array}{l}\text { - Inflammatory status } \downarrow \\
\text { - Antiviral activity } \uparrow \\
\text { - Prevents thromboembolism }\end{array}$ & $(65,66)$ \\
\hline Zinc & $\begin{array}{l}\text { - Antioxidative and anti-inflammatory properties in high-risk adults } \\
\text { - Reduction of inflammatory cytokine production } \\
\text { - Regulation of Th1/Th2 balance } \\
\text { - Inhibition of ACE2 } \\
\text { - Exert antiviral effect }\end{array}$ & $\begin{array}{l}\text { - Inflammatory status } \downarrow \\
\text { - Immunity } \uparrow \\
\text { - Probably insulin resistance } \downarrow \\
\text { - Probably viral replication } \downarrow\end{array}$ & $(67-73)$ \\
\hline Copper & $\begin{array}{l}\text { - Regulation of Th1/Th2 balance } \\
\text { - Reduction of inflammatory cytokine production } \\
\text { - Oxidizing activity }\end{array}$ & $\begin{array}{l}\text { - Inflammatory status } \downarrow \\
\text { - Antiviral activity } \uparrow\end{array}$ & $(74-76)$ \\
\hline Magnesium & $\begin{array}{l}\text { - Reduction of inflammatory cytokine production } \\
\text { - Regulation of M1/M2 macrophage } \\
\text { - Inhibits PARP }\end{array}$ & $\begin{array}{l}\text { - Inflammatory status } \downarrow \\
\text { - Prevents thromboembolism } \\
\text { - Lung damage prevention }\end{array}$ & $(77,78)$ \\
\hline
\end{tabular}

that SARS-CoV/CoV-2 affects the pulmonary lipofibroblast transcriptional program that leads to pulmonary fibrosis, the use of peroxisome proliferator-activated receptor-gamma (PPAR $\gamma)$ agonists could be an option to reduce the risk of pulmonary fibrosis. This strategy may show strong anti-fibrotic effects that disrupt myofibroblast differentiation and transforming growth factor-beta (TGF- $\beta$ ) signaling. PPARy induction could lead to an effective reduction of the problem and organ fibrotic disease, including pulmonary fibrosis (81) by decreasing the fat mass of adiponectin (82).

The Spike glycoprotein (S), a structural protein of SARS$\mathrm{CoV}-2$, is responsible for binding to the host cell. Hoffmann et al. (83) reported that $S$ protein is primed serine protease and recognized by the cell receptor. Liu et al. (84) showed that the S protein of SARS-CoV-2 had two trimers that bind to the ACE2 heterodimer. Dipeptidyl peptidase 4 (DPP4) is a ubiquitous membrane-bound aminopeptidase that circulates in the plasma has multifunctional roles in metabolism, immunity, and the endocrine system. DPP4 regulates glucose homeostasis and inflammation differently through its immunomodulatory properties. Bassendine et al. (85) reported that obesity and metabolic syndrome strongly affect the severity of COVID-19 by modulating the DPP4 expression.

In COVID-19, loss of the ACE2 enzyme that converts angiotensin-II to angiotensin-I may lead to insulin resistance (86) and endothelial cell dysfunction (87). Although the lung tissue is the primary target of SARS-CoV-2, ACE2 protein expression levels in adipose tissue (80) and pancreas (88) are higher than in the lung. High-level ACE2 expression in the pancreas may predispose to viral pancreatitis (88) and subsequently diabetes as a complication. Therefore, obese individuals may be at higher risk for metabolic complications of COVID-19.

\section{MICRONUTRIENTS AND COVID-19 PATIENTS WITH OBESITY}

The insufficiency of micronutrients including vitamin $\mathrm{A}$, vitamin $\mathrm{D}$, vitamin $\mathrm{E}$, vitamin $\mathrm{B} 1$, vitamin $\mathrm{B} 6$, vitamin $\mathrm{B} 12$, vitamin $\mathrm{C}, \mathrm{Fe}, \mathrm{Zn}$, and Se, called "latent hunger" causes 
important health problems globally. Correa-Rodríguez et al. (89) observed significant reductions in vitamin C, vitamin A, and Se intake in overweight or obese young adults. Therefore, the supplementation of micronutrients may support the body's natural defense system by enhancing immunity, epithelial barriers, cellular immunity, and antibody production (90).

\section{Vitamins \\ Vitamin A}

Vitamin A is accepted as an anti-inflammatory or anti-infective micronutrient owing to its immunomodulatory, and epithelial cell repairing functions (55). Vitamin A has been shown to reduce the severity of viral pneumonia caused by an avian coronavirus (91), measles (92), influenza A, rotavirus, and Newcastle disease virus (93). Therefore, retinoids could potentially inhibit the replication of SARS-CoV-2 and thereby reduce the severity of COVID-19 (94). Furthermore, the vitamin A derivate named isotretinoin (54) may interfere with the cellular uptake of SARS-CoV-2 and its lung-directed pathogenicity by inhibiting the ACE2 (95). Administration of all-trans retinoic acid in a hypoxia/reoxygenation model increased the mRNA expression of ACE2 and down-regulated the mRNA expression of ACE1 and TGF- $\beta 1$ in renal tubular epithelial cells (96). In individuals with low vitamin A levels, histopathological changes have been detected in pulmonary epithelia and lung parenchyma, along with an increased risk of pulmonary dysfunction and respiratory disease (97). Normal serum retinol levels may mask the severity of vitamin A deficiency in obesity (98). The continuous consumption of the western diet reduces tissue vitamin A levels (99). Vitamin A deficiency and increased expression of leptin, enhance the levels of pro-inflammatory cytokines that contribute to the systemic inflammation in obesity (100). Penkert et al. (98) reported that vitamin A supplementation protects against a respiratory virus infection by controlling respiratory virus clearance, decreasing inflammatory cytokines in the blood, and altering the lung immune capacity in obese C57BL/6 mice. In addition, high doses of oral vitamin A supplementation has been shown to reduce obesity by upregulating brown adipose tissueuncoupling protein1 (BAT-UCP1) expression in the WNIN/Ob rat model (101). Considering the effects of COVID-19 on lung function and protective properties of vitamin A in the organism, vitamin $A$ is expected to have a beneficial effect in obese COVID19 patients.

\section{Vitamin C}

Vitamin $\mathrm{C}$ has been used to boost the antiviral host immune defense (56), reduce or prevent the symptoms of the common cold and other respiratory infections caused by viruses $(102,103)$. Vitamin $\mathrm{C}$ regulates the immune responses in the early stage of influenza infection through increasing the levels of type I interferons (IFN- $\alpha$ and IFN- $\beta$ ) (104) having critical functions to attenuate viral pathogenesis (105). Vitamin C is an effective intracellular antioxidant for biomolecules and has significant ROS scavenging activity that results in the inhibition of the inflammatory NF- $\beta \beta$ signal transduction pathway (56). In addition, the phagocytic activity of neutrophils and macrophages is regulated by their vitamin C content (106). Supplemental vitamin C may decrease the severity of obesity and its comorbidities by regulating lipid accumulation, inhibiting lipolysis that reduces systematic FFA efflux, and glucocorticoid production, reducing ROS activity and interfering adipocyte macrophages, thus decrease pro-inflammatory adipokines (leptin) and cytokines (107). In a meta-analysis of eight randomized clinical trials in 3,135 children aged 3 months to 18 years, vitamin $\mathrm{C}$ administration decreased to the duration of upper respiratory tract infection by 1.6 days. In the same study, it was reported that children 6 years of age benefit from more effective vitamin $\mathrm{C}$ administration associated with Echinacea (108). In a randomized, double-blind, placebo-controlled, phase I trial, ascorbic acid infusion rapidly increased plasma ascorbic acid concentration and reduced the pro-inflammatory biomarkers C-reactive protein (CRP) and procalcitonin levels, prevented an increase in thrombomodulin levels consistent with reduced vascular damage, and caused reductions in sequential organ failure assessment scores (109). In addition, a time-delayed infusion protocol of both ascorbic acid and dehydroascorbic acid attenuated pro-inflammatory, procoagulant states that induce lung vascular damage and significantly prolonged survival (110). In obesity, low vitamin $\mathrm{C}$ status correlates with inflammatory reactions and vascular dysfunction (111), and a dose of $1 \mathrm{~g} /$ day vitamin $\mathrm{C}$ treatment for 8 weeks could reduce CRP and IL-6 levels in both hypertensive and diabetic obese patients (112). In higher doses, vitamin $\mathrm{C}$ can act as an oxidizing agent (106). The oxidizing properties of vitamin $\mathrm{C}$ are boosted with the presence of iron, increasing its antiviral activity via the Fenton reaction that results in the production of hydrogen peroxide and hydroxyl radicals (113). The different doses of vitamin C supplementation (125 and $250 \mathrm{mg} / \mathrm{kg}$ ) reduced mitochondrial antiviral signaling, interferon-regulating factor 3, and steroid hydroxylase in mice exposed to restraint stress and H1N1-induced pneumonia (114). Recently, Peng (115) started a randomized controlled vitamin C infusion trial that aims to attenuate the respiratory symptoms of COVID-19 infection. High-dose vitamin C might be an effective choice in the early treatment of COVID-19 (116). Consumption of citrus fruits and vegetables containing vitamin $\mathrm{C}$ has been proposed as a low-cost strategy to support the immune system during the COVID-19 pandemic (11).

\section{Vitamin D}

There are multiple variables such as age, body mass index, skin color, and genetic variants that can affect the vitamin $\mathrm{D}$ stores of the body (117). Low serum 25-hydroxyvitamin D [25(OH)D] concentrations have been reported in obese humans and an inverse relationship between BMI and serum 25(OH)D has been reported in obese humans (118). Lin et al. (119) were observed that vitamin D deficiency $[25(\mathrm{OH}) \mathrm{D}<20 \mathrm{ng} / \mathrm{mL}]$ and insufficiency $[20<25(\mathrm{OH}) \mathrm{D}<30 \mathrm{ng} / \mathrm{mL}]$ in 52 obese (mean BMI $37.6 \pm 6.4 \mathrm{~kg} / \mathrm{m}^{2}$ ) were at 73 and $22 \%$ prevalence. Vitamin D metabolizing enzyme expression (Cyp2r1, Cyp27a1, and Cyp2j3) was affected by high fat diet-induced obesity, which may partially explain the mechanisms of the modified vitamin D endocrine system related to obesity (120). Adequate daily intake of vitamin $\mathrm{D}$ is thought to curb viral infections $(121,122)$. Seasonal viral infections affecting the respiratory tract as well as COVID-19 may 
be facilitated by vitamin $\mathrm{D}$ deficiency $(123,124)$. The serum levels of $25(\mathrm{OH}) \mathrm{D}$, the circulating metabolite of vitamin $\mathrm{D}$, are inversely correlated with pulmonary inflammation (125) and directly correlated with the pulmonary function (120) as well as host immune response (126) during respiratory virus infection. 1,25dihydroxyvitamin $\mathrm{D}(1,25 \mathrm{D})$, an active metabolite of vitamin $\mathrm{D}$, has pleiotropic effects on immune system elements (57, 127-129) and may reduce the production of pro-inflammatory cytokines that have been implicated in the pathophysiology of COVID-19 associated ARDS (IFN- $\gamma$, TNF- $\alpha$, IL-1, IL-6, IL-2, IL-12, and IL-17) (Figure 3) (130). Administration of vitamin $\mathrm{D}$ stimulated binding of the SARS-CoV-2 cell entry receptor ACE2 to angiotensin-II receptor type 1, decreasing the number of virus particles that could attach to ACE2 and enter the cell (131, 132). Therefore, vitamin $D$ supplementation could potentially reduce the incidence of severe COVID-19 (124). In randomized controlled trials of vitamin $\mathrm{D}$ for prevention of respiratory tract infection (Of 1,137 citations retrieved, 11 placebo-controlled studies of 5,660 patients), vitamin $\mathrm{D}$ showed a protective effect against respiratory tract infection, with daily dosing appearing to be the most effective strategy (133). That being said, a clinical study conducted by Hastie et al. (134) indicated that the relation between COVID-19 and serum vitamin D levels was not significant. Additionally, the intake of high doses of vitamin D may have harmful effects on COVID-19 patients (124).

\section{Vitamin E}

Vitamin E supplementation generally reduces the severity of infectious diseases, owing to antioxidant and immunomodulatory effects (135). Tocopherols ( $\alpha$ and $\gamma$ ), natural vitamin $\mathrm{E}$ isomers, exhibits ROS scavenging activity (58) and can block acute neutrophil inflammation in the lung (59). Dietary vitamin E deficiency may increase IL-1 induced lung leak in rats (136), and probably provokes acute hyperoxic lung injury related to IL-6 and 8-iso-prostaglandin $\mathrm{F}_{2 \alpha}$ stimulated inflammation in mice (137). Oral vitamin E intake is positively associated with lung health (138). In a randomized clinical trial performed by Agler et al. (139) proved that a dose of $600 \mathrm{IU}$ vitamin $\mathrm{E}$ (every other day) reduced the risk of chronic lung disease. No studies have been done in the case of the link between vitamin E and COVID-19 patients with obesity. Meydani et al. (140) found that a daily intake of 200 IU vitamin E has not any effect on lower respiratory infection. In the same study, the incidence of upper respiratory infections such as common cold found lower in older people.

After ACE2 mediated cell entry, coronaviruses firstly activate aryl hydrocarbon receptors (AhRs) without indoleamine 2,3dioxygenase (IDO1) stimulation (141). Activated AhRs initiates the production of inflammation factors (IL-1 $\beta$, IL- 6 , and TNF- $\alpha$ ), induces tissue factor (TF) and PAI-1 mediated thromboembolism (AhR-TF/PAI-1 pathway) (142), and lead multiple organ fibrosis via Cytochrome P450, family 1, subfamily A, polypeptide 1 (CYP1A1)/IL-22 signaling pathway with signal transducer and activator of transcription 3 (STAT3) (143). The produced inflammatory cytokines trigger IDO1 that metabolizes tryptophan to kynurenine (AhR stimulator). Consequently, these signaling factors lead to the IDO1-AhR-IDO1 loop (Figure 3)
(141). AhR signaling pathway stimulation also modulates obesity via disrupting fat metabolism (144). The degree of AhR activation raises depend on the severity of obesity due to enhanced inflammatory factors, including TLR2/4- NF- $\kappa \beta$ mediated (145). Likewise, elevated dietary fat intake increases the level of serum (low-density-lipoprotein) LDL (146) that responsible for the AhR activation (147). SARS-CoV-2 induced IDO1-AhR-IDO1 loop might be exponentially increased in obese COVID-19 patients, and probably inhibited by vitamin D for AhR (148), and vitamin E for IDO1 (149). Therefore, using both vitamin D and E together most likely reduces the clinical symptoms in COVID-19 infection and obesity-associated complications.

\section{B Vitamins}

The prevention or treatment of lung damage is critical for the survival outcome of COVID-19 patients. Vitamin B3, a claimed protector of lungs, can promote the healing of tissue damage in the lungs $(60,61)$, most likely owing to its ability to inhibit the poly ADP ribose polymerase (PARP) (61). Because the increased activity of PARP elevates the inflammatory cytokines that contribute to the cytokine storm, vitamin B3 therapy may reduce cytokine storm in COVID-19 (6). The pyridine-nucleoside form of vitamin B3 called nicotinamide riboside functions as a precursor to nicotinamide adenine dinucleotide $\left(\mathrm{NAD}^{+}\right)$, prevented ALI/ARDS and heart injury, and improved the survival of mice after the LPS challenge or sepsis caused by intraperitoneal injection of feces (150). In LPSchallenged rats, the administration of nicotinamide prevented the decrease in mitochondrial respiration and intracellular $\mathrm{NAD}^{+}$levels in macrophages (151). In obesity, adipose tissue nicotinamide phosphoribosyltransferase (NAMPT) expression reduces, and $\mathrm{NAD}^{+}$biosynthesis impairs. The reduction in $\mathrm{NAD}^{+}$levels causes decreasing adiponectin and increasing FFA production (152). The dietary supplementation of $\mathrm{NAD}^{+}$ precursors alleviates inflammation, improves insulin sensitivity, and reduces body weight gain in obesity (153).

Vitamin B6 levels and the severity of inflammatory reactions are inversely correlated $(154,155)$. The utilization of vitamin B6 rapidly increases under inflammatory conditions, and COVID19 patients probably may have vitamin B6 deficiency (156). Vitamin B6 downregulated the pulmonary inflammation by inhibiting macrophage activation, as reduced production of IL$1 \beta$, IL-6, and TNF- $\alpha$ in macrophages challenged with LPS of mice (155). In a rat model of systemic inflammation, orally administered $500 \mathrm{mg} / \mathrm{kg}$ riboflavin and $600 \mathrm{mg} / \mathrm{kg}$ thiamine increased the anti-inflammatory activity of dexamethasone, along with reducing TNF- $\alpha$ and IL- 6 production (157). The relationship between dexamethasone and thiamine caused more inhibition of IL-6 production compared to dexamethasoneinduced. Multivitamin supplementation within $48 \mathrm{~h}$ of hospital admission, including thiamine, riboflavin, and niacin was associated with lower overall mortality in patients with Ebola Virus Disease (158).

The folic acid and its derivates such as tetrahydrofolic acid and 5-methyl tetrahydrofolate may interfere with the cell entry of SARS-CoV 2 (63) via inhibition of furin protein that has essential for COVID-19 progression (159). In addition to the 


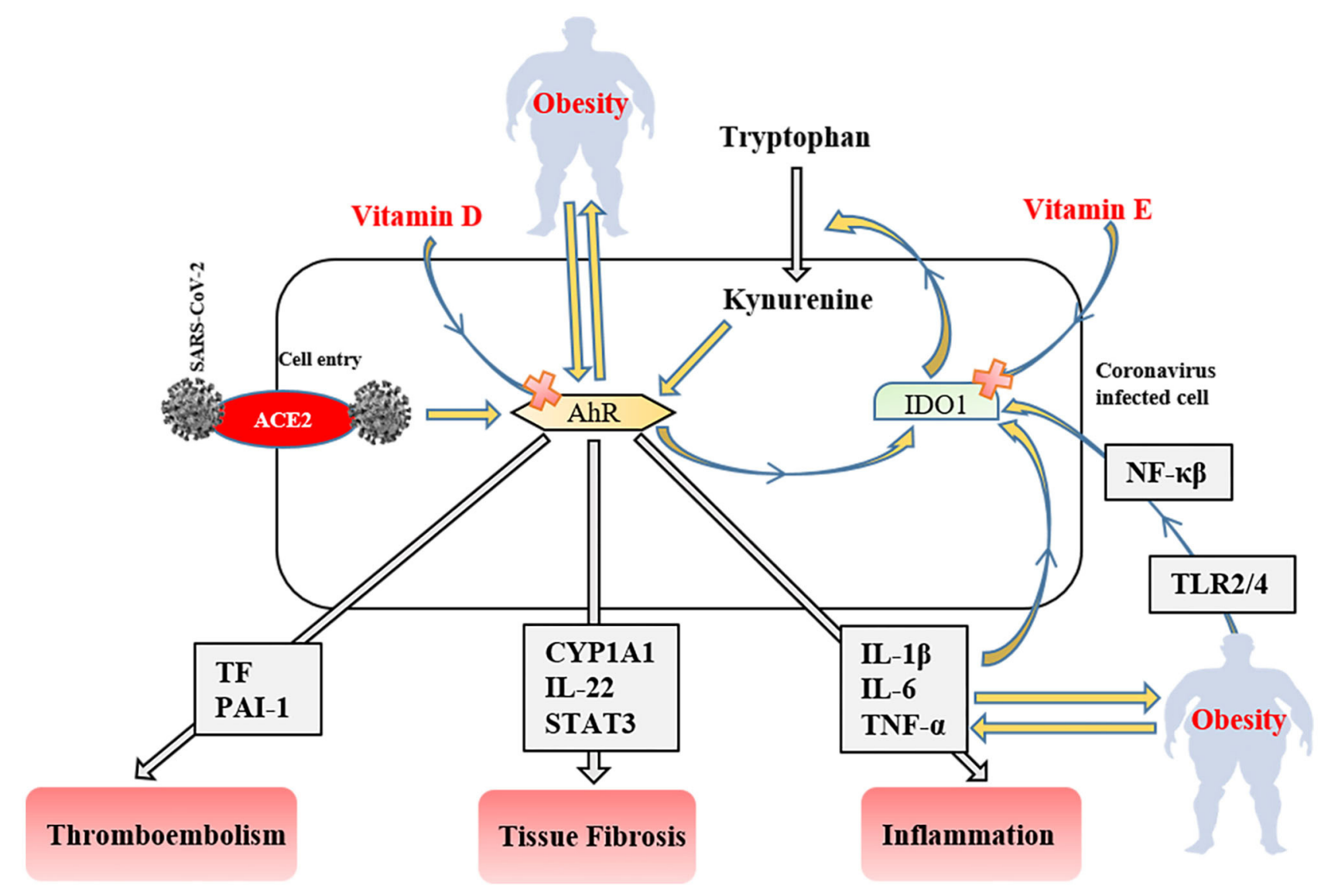

FIGURE 3 | The role of the IDO1-AhR-IDO1 signaling loop in obese COVID-19 patients. AhR, aryl hydrocarbon receptors; IDO1, indoleamine 2,3-dioxygenase; ACE2, angiotensin-converting enzyme 2; NF-к $\beta$, nuclear factor-kappa $\beta$; TLR, tool-like receptor; PAl-1, plasminogen activator inhibitor-1; CYP1A1, Cytochrome P450, family 1, subfamily A, polypeptide 1; STAT3, signal transducer and activator of transcription 3; TNF- $\alpha$, tumor necrosis factor-alpha IL; interleukin TF, tissue factor.

ACE2 protein, S-glycoprotein, some of the proteases $\left(\mathrm{M}^{\mathrm{pro}}\right.$ and $\left.\mathrm{PL}^{\mathrm{pro}}\right)$, RNA dependent RNA polymerase, and Nsp15 promote the cellular entry of SARS-CoV $2(63,160)$. In a virtual screening study among the 106 nutraceuticals, the folic acid and folic acid derivates were identified as potential agents that could have potential in post-exposure prophylaxis (63).

The deficiency of some B vitamins (folic acid, B6, and B12) and dietary essential amino acid methionine results in hyperhomocysteinemia that leads to venous thromboembolism (64). In obesity, the high cardiovascular risk that is related to hyperhomocysteinemia correlates with insufficient nutritional status of folate and vitamin B12. The decreased levels of plasma folate and vitamin B12 are accepted as a predictor of vascular dysfunction (161). A high dose of vitamin B6 administration may reduce the TNF- $\alpha$, IL- 6 , and D-dimer levels and improves endothelial integrity along with preventing coagulopathy in COVID-19 patients (156).

\section{Minerals}

\section{Magnesium}

Magnesium can alleviate inflammatory disorders, including obesity (162) and respiratory infections (78). The M1 type macrophages producing NF- $\kappa \beta$ depended on pro-inflammatory mediators shifts to M2 type macrophages after Mg treatment and stimulates the anti-inflammatory cytokine secretion (77). The low dietary Mg intake inversely was associated with endothelial cell dysfunction and biomarkers of systemic inflammation (163). Different forms of $\mathrm{Mg}$ could be used against various lung diseases (164). Li et al. (78) reported that $\mathrm{MgSO}_{4}$ administration reduced the PARP-1 and apoptosis-inducing factor levels in LPS induced ALI mice. Recently Tan et al. (165) observed that the administration of oral vitamin $\mathrm{D}, \mathrm{Mg}$, and vitamin B12 combination reduces the clinical deterioration in COVID19 patients. Mg nutrition may be an effective strategy for the treatment and prevention of COVID-19 infection (166, 167). Moreover, many diseases, such as obesity that cause $\mathrm{Mg}$ deficiency (162), probably exacerbate the clinical symptoms of COVID-19.

\section{Selenium}

Selenium is considered an important antioxidant trace mineral. The severity and mortality of viral infections were inversely correlated with serum Se levels in several studies (168-170). Virulence and pathogenesis levels of viruses can be increased 
due to the weakened immune system after the long term intake of inadequate Se containing diets (171). The M1 type macrophages increase with Se deficiency or low Se intake (65, 172). However, high amounts of Se intake lead to shifts Th2 phenotype to the Th1 phenotype (173). Zhang et al. (174) recently reported that Chinese persons with lower hair Se content had more severe COVID-19 infections. Se supplementation may therefore have clinical utility in COVID-19 pending further confirmation of the prognostic role of Se for the survival outcome of COVID-19 patients. Fakhrolmobasheri et al. (175) reported that Se could prevent cell death caused by viral replication. In patients with ARDS, sodium selenite ( $1 \mathrm{mg}$ for 3 days and $1 \mathrm{mg} / \mathrm{d}$ for a further 6 days) supplementation replenished Se levels and Se concentrations were positively correlated with antioxidant activity. Serum concentrations of IL-1 $\beta$ and IL6 were inversely associated with serum Se concentrations. Nevertheless, there was no effect on overall survival, mechanical ventilation time, and length of stay in intensive care (176). In LPS-stressed RAW264.7 cells, LPS increased mRNA profiles of inflammatory genes, while short-time Se pretreatment reduced the LPS-induced upregulation of cyclooxygenase-2, intercellular adhesion molecule-1, IL-1 $\beta$, IL-6, IL-10, nitric oxide synthase, and monocyte chemoattractant protein- 1 and further increased expression of IFN- $\beta$ and TNF- $\alpha$ (177). In the same study, LPS decreased mRNA levels of selenoprotein encoding genes, whereas increased mRNA levels of thioredoxin reductases (TXNRD1and TXNRD3) in cells. Se deficiency or overexposure impairs the selenoprotein synthesis (glutathione peroxidase and TXNRDs) that cause adipocyte dysfunction leading to various metabolic disorders. The expression of these selenoproteins is decreased in obese individuals due to their lower Se status (178). In COVID-19, selenoprotein expression may also be reduced by inflammatory factors and suppressed immune status (179). Therefore, dietary Se supplementation may help alleviate the respiratory and inflammatory clinical symptoms in obese patients suffering from COVID-19.

\section{Zinc}

Zinc is another important trace mineral to improve the immune functions against viral infections $(180,181)$. In risk groups for $\mathrm{Zn}$ deficiency, including aging, immune deficiency, obesity, diabetes, and atherosclerosis, low Zn status may relate to severe COVID19 risk (182). Zn can exert its antiviral effect by suppressing viral replication, improvement of mucociliary clearance and increasing immune responses, prevention of lung injury, and regulation of antiviral and antibacterial immunity (73). Zn can provide low-cost and effective adjunctive therapy for some viral diseases, including respiratory infections (183). For example, Mossad et al. (184) reported that the duration of common cold symptoms was shortened from 7.6 to 4.4 days with zinc gluconate (containing $13.3 \mathrm{mg}$ elemental $\mathrm{Zn}$ ). In vitro studies showed that $\mathrm{Zn}$ exhibits antiviral activity by inhibiting the SARS-CoV RNA polymerase (73). Indirect data suggest that $\mathrm{Zn}$ may decrease the activity of ACE2. The anti-inflammatory activity of Zn depends on NF- $\kappa$ B signaling pathway inhibition and modulation of Treg function, which may help reduce the risk of cytokine storm in COVID-19 (73). In addition, $\mathrm{Zn}$ has been revealed to be vital for respiratory epithelium, owing to antioxidant and antiinflammatory activity (185), and also the regulation of tightly binding proteins zonula occludens-1 and Claudin-1, thereby enhancing barrier functions (186). In an in-vitro study was demonstrated that $\mathrm{Zn}$ administration (10 $\mu \mathrm{m} \mathrm{Zn}$ preincubation) inhibited respiratory syncytial virus replication by more than 1.000 -fold reduction (187). Antiviral agent chloroquine, a $\mathrm{Zn}$ ionosphere that is used in the treatment of COVID-19, increases the $\mathrm{Zn}$ transport into the cells $(73,188,189)$. It has recently been proposed that the severity of COVID-19 infection could be reduced with an adequate daily intake of $\mathrm{Zn}$ (183). Recently, Finzi (190) reported that high dose oral supplementation of $\mathrm{Zn}$ salts (zinc citrate, zinc gluconate, or zinc acetate) reduced the respiratory clinical symptoms of COVID-19 patients (190). In line with this information, it was suggested that $\mathrm{Zn}$ could be one of the most promising micronutrients for COVID-19 prevention or treatment $(191,192)$. The effects of $\mathrm{Zn}$ on obesity and respiratory viral infections may help to treatment of COVID19 in both obese and overweight patients.

\section{Copper}

Copper $(\mathrm{Cu})$, a trace mineral, has an important role in host immunity against viruses, regulating inflammatory responses, and boosting the immunity of the host in many infections (193198). Elevating the $\mathrm{Cu}$ levels in the lung tissue has been suggested as a strategy for treating or preventing pulmonary inflammation (199). The appropriate dietary $\mathrm{Cu}$ intake within normal daily limits probably increases the number of phagocytic cells, the activity of Natural killer cells, the proliferation of Th cells (200), and more importantly the Th1-stimulated production of IL-2, but not TNF- $\alpha$ (75). In this context, $\mathrm{Cu}$ is may require to maintain the balance of the Th1/Th2 profile (74). The increased proinflammatory cytokine TNF- $\alpha$ causes decreasing Cu levels in the lungs during lung infections (199). Raha et al. (201) hypothesized that $\mathrm{Cu}$ supplementation could protect the high-risk COVID-19 patient populations with $\mathrm{Cu}$ deficiency from developing ARDS.

In addition, the raising of the ROS concentration may be used to exhibit the antiviral action by $\mathrm{Cu}$ (76). The $\mathrm{Cu}$-peroxide complexes could enhance the effectiveness of this action (202). Since ROS production properties of $\mathrm{Cu}$ containing surfaces, SARS-CoV and SARS-CoV-2 viruses are sensitive to $\mathrm{Cu}$ alloys $(203,204)$. However, $\mathrm{Cu}$ supplementation may also increase the risk of sepsis and ARDS and should not be attempted outside a well-controlled clinical trial.

\section{OTHER IMPORTANT NUTRIENTS IN COVID-19}

\section{Flavonoids}

Plant-derived flavonoids having anti-inflammatory, antioxidant, and antimicrobial activities (205) also have anti-obesity and anti-diabetic potential (206). In obesity and other inflammatory disorders, dietary flavonoids could inhibit inflammatory cytokine production, leptin secretion, insulin resistance, and improve immune responses (207). Polyphenols inhibit NF-кB and activator protein-1 activates nuclear factor erythroid 2-related 
factor 2 (Nrf2) and improves lipid profiles via enhancing HDLcholesterol, while the reduction in LDL-cholesterol. Therefore, the intake of high-polyphenol diets shows various antioxidant, anti-inflammatory, and dyslipidemia-reducing effects (182). Vernarelli and Lambert (208) reported that dietary flavonoid consumption was inversely correlated with the severity of obesity and serum CRP levels. The inhibition of inflammatory cytokines by flavonoids (205) in the context of pulmonary infection $(209,210)$ may prevent the development of or reduce the negative consequences of the cytokine storm in COVID19. Additionally, the coagulopathy associated with COVID19 may be alleviated by flavonoids through the reduction of endothelial TF availability (211). Both in vitro and in vivo studies indicate that flavonoids exhibit antiviral activity against respiratory tract viruses including SARS-CoV and influenza (212). In a meta-analysis performed by Somerville et al. (213), flavonoids have been shown to potentially reduce the incidence of upper respiratory tract infections caused by viruses. In silico virtual computational screening studies have been demonstrated that natural compounds like flavonoids may inhibit SARS-CoV-2 by binding to S proteins that have an affinity to ACE2 (214). Also, Adem et al. (215) demonstrated that flavonoids may inhibit $M^{\text {pro }}$ used by SARS-CoV-2 for viral replication. Especially, quercetin and catechins have antiviral activity on SARS-CoV (216), and probably on SARS-CoV $2(217,218)$. In addition, curcumin $(219,220)$ indomethacin and resveratrol have been proposed as potential supportive care supplements against COVID-19 (221).

\section{Lactoferrin}

Lactoferrin, which shows antimicrobial activity, has antiinflammatory and immunomodulatory activities (222). Due to its antiviral activity, many viruses, including SARS-CoV (223), could be killed by lactoferrin (224-226). The reported antiviral action of lactoferrin against SARS and COVID-19 most probably stems from blocking the activity of ACE2 and Heparan Sulfate Proteoglycan, which are required for cell entry of SARS-CoV and SARS-CoV 2 (227). Additionally, a clinical study performed by Serrano et al. (228) indicated that bovine liposomal lactoferrin using combined with vitamin $\mathrm{C}$ and $\mathrm{Zn}$ attenuated symptoms of COVID-19 infection. Likewise, lactoferrin can alleviate obesity by inhibiting leptin production and controlling LPS releasing from gut microbiota (229). In this context, the leptin reducing functions of $\mathrm{Zn}$ and vitamin $\mathrm{C}$ (230) when combined with lactoferrin may be beneficial in the treatment of COVID-19 in obese individuals.

\section{Essential Fatty Acids}

Dietary polyunsaturated fatty acids (PUFAs) and their metabolites exert protective effective effects during systemic

\section{REFERENCES}

1. World Health Organization. WHO Coronavirus Disease (COVID-19) Dashboard, (2020) Available online at: https://covid19.who.int/(accessed July $17,2020)$. inflammation (231). Supplementation of n-3 PUFAs reduces the systemic inflammation of non-diabetic obese patients (232). EPA and DHA may inhibit the inflammatory NF-кB and TLR signaling pathways (233). These long-chain fatty acids also decrease the M1/M2 macrophage ratio in adipose tissues, thereby reducing the inflammatory state and decreasing the insulin resistance (234). Omega-3 PUFAs and its lipid derivatives such as resolvins, and protectins (protectin D1), when used at appropriate dose levels and according to rational administration schedules, could be potentially useful in reducing the pro-inflammatory cytokine production that leads to cytokine storm in COVID-19 (235). Importantly, omega-3 and omega-6 PUFAs have been shown to reduce platelet aggregation and may therefore prevent thrombosis (236) and reduce the risk of thromboembolic complications in COVID-19 patients that have been associated with a poor survival outcome (237).

\section{CONCLUSION}

A deficiency of micronutrients due to malnutrition has the potential to increase the severity of viral infections. Many essential nutrients like vitamins, minerals, amino acids, and fatty acids are important for the pleiotropic functions of our immune system. Balanced nutrition and intake of nutrients in appropriate amounts and composition may reduce the levels of pro-inflammatory cytokines and their side effects in COVID-19 patients. More importantly, obese COVID-19 patients are more susceptible to inflammation, lung diseases, coagulopathy, and probably insulin resistance than lean patients. Some in vitro and in silico studies suggested that specific nutrients might exhibit protective effects against COVID-19 infection. However, further studies are needed to improve our current knowledge about the emerging role of supplemental nutrients as adjuncts to the supportive care for obese COVID-19 patients.

\section{AUTHOR CONTRIBUTIONS}

KS and ES conceived the study, participated in its design and coordination, and drafted and authored the manuscript. $\mathrm{CO}$ and $\mathrm{FU}$ participated in the study design, interpretation of the data, and helped to draft manuscript revisions. All authors have read and approved the final manuscript.

\section{FUNDING}

This research was funded by the Turkish Academy of Science (Ankara, Turkey).
2. Wu D, Wu T, Liu Q, Yang Z. The SARS-CoV-2 outbreak: what we know. Int J Infect Dis. (2020) 94:44-8. doi: 10.1016/j.ijid.2020.03.004

3. Jordan RE, Adab P, Cheng KK. Covid-19: risk factors for severe disease and death. BMJ. (2020) 368:m1198. doi: 10.1136/bmj. m1198 
4. Weiss SR, Leibowitz JL. Chapter 4 - coronavirus pathogenesis. In: Maramorosch K, Shatkin AJ, Murphy FA, editors. Advances in Virus Research. 81. Cambridge: Academic Press (2011) p. 85-164.

5. Su S, Wong G, Shi W, Liu J, Lai ACK, Zhou J, et al. Epidemiology, genetic recombination, and pathogenesis of coronaviruses. Trends Microbiol. (2016) 24:490-502. doi: 10.1016/j.tim.2016.03.003

6. Calder PC. Nutrition, immunity and COVID-19. BMJ Nutr Prev Health. (2020) 3:85. doi: 10.1136/bmjnph-2020-000085

7. Pedersen SF, Ho Y-C. SARS-CoV-2: a storm is raging. J Clin Invest. (2020) 130:2202-5. doi: 10.1172/JCI137647

8. Huang C, Wang Y, Li X, Ren L, Zhao J, Hu Y, et al. Clinical features of patients infected with 2019 novel coronavirus in Wuhan, China. Lancet. (2020) 395:497-506. doi: 10.1016/S0140-6736(20)30183-5

9. Chandra RK, Sarchielli P. Nutritional status and immune responses. Clin Lab Med. (1993) 13:455-61. doi: 10.1016/S0272-2712(18)30448-7

10. Cena H, Chieppa M. Coronavirus disease (COVID-19-SARS-CoV-2) and nutrition: is infection in Italy suggesting a connection? Front Immunol. (2020) 11:944. doi: 10.3389/fimmu.2020.00944

11. Kalantar-Zadeh K, Moore LW. Impact of nutrition and diet on COVID19 infection and implications for kidney health and kidney disease management. J Renal Nutr. (2020) 30:179-81. doi: 10.1053/j.jrn.2020.03.006

12. Taylor AK, Cao W, Vora KP, Cruz JDL, Shieh W-J, Zaki SR, et al. Protein energy malnutrition decreases immunity and increases susceptibility to influenza infection in mice. J Infect Dis. (2013) 207:501-10. doi: 10.1093/infdis/jis527

13. Galli F, Reglero G, Bartolini D, Visioli F. Better prepare for the next one. Lifestyle lessons from the COVID-19 pandemic. Pharma Nutr. (2020) 12:100193. doi: 10.1016/j.phanu.2020.100193

14. Liu W, Tao Z-W, Wang L, Yuan M-L, Liu K, Zhou L, et al. Analysis of factors associated with disease outcomes in hospitalized patients with 2019 novel coronavirus disease. Chin Med J. (2020) 133:10328. doi: 10.1097/CM9.0000000000000775

15. Wu C, Chen X, Cai Y, Xia Ja, Zhou X, Xu S, et al. Risk factors associated with acute respiratory distress syndrome and death in patients with coronavirus disease 2019 Pneumonia in Wuhan, China. JAMA Int Med. (2020) 180:111. doi: 10.1001/jamainternmed.2020.0994

16. Keller U. Nutritional laboratory markers in malnutrition. J Clin Med. (2019) 8:775. doi: $10.3390 / \mathrm{jcm} 8060775$

17. Caccialanza R, Laviano A, Lobascio F, Montagna E, Bruno R, Ludovisi $\mathrm{S}$, et al. Early nutritional supplementation in non-critically ill patients hospitalized for the 2019 novel coronavirus disease (COVID-19): rationale and feasibility of a shared pragmatic protocol. Nutrition. (2020) 74:110835. doi: 10.1016/j.nut.2020.110835

18. Draganidis D, Karagounis LG, Athanailidis I, Chatzinikolaou A, Jamurtas AZ, Fatouros IG. Inflammaging and skeletal muscle: can protein intake make a difference? J Nutr. (2016) 146:1940-52. doi: 10.3945/jn.116.230912

19. Katsanos CS, Chinkes DL, Paddon-Jones D, Zhang X-j, Aarsland A, Wolfe RR. Whey protein ingestion in elderly persons results in greater muscle protein accrual than ingestion of its constituent essential amino acid content. Nutr Res. (2008) 28:651-8. doi: 10.1016/j.nutres.2008.06.007

20. Hashemilar M, Khalili M, Rezaeimanesh N, Sadeghi Hokmabadi E, Rasulzade S, Shamshirgaran SM, et al. Effect of whey protein supplementation on inflammatory and antioxidant markers, and clinical prognosis in acute ischemic stroke (TNS Trial): a randomized, double blind, controlled, clinical trial. Adv Pharm Bull. (2020) 10:135-40. doi: 10.15171/apb.2020.018

21. Kiewiet BGM, Faas MM, De Vos P. Immunomodulatory protein hydrolysates and their application. Nutrients. (2018) 10:904. doi: 10.3390/nu10070904

22. Ng TB, Cheung RCF, Wong JH, Wang Y, Ip DTM, Wan DCC, et al. Antiviral activities of whey proteins. Appl Microbiol Biotechnol. (2015) 99:6997-7008. doi: 10.1007/s00253-015-6818-4

23. Calder PC. Omega-3 polyunsaturated fatty acids and inflammatory processes: nutrition or pharmacology? Br J Clin Pharmacol. (2013) 75:64562. doi: 10.1111/j.1365-2125.2012.04374.x

24. Baker EJ, Miles EA, Burdge GC, Yaqoob P, Calder PC. Metabolism and functional effects of plant-derived omega-3 fatty acids in humans. Prog Lipid Res. (2016) 64:30-56. doi: 10.1016/j.plipres.2016.07.002
25. Husson M-O, Ley D, Portal C, Gottrand M, Hueso T, Desseyn J$\mathrm{L}$, et al. Modulation of host defence against bacterial and viral infections by omega-3 polyunsaturated fatty acids. J Infect. (2016) 73:52335. doi: 10.1016/j.jinf.2016.10.001

26. Viardot A, Heilbronn LK, Samocha-Bonet D, Mackay F, Campbell LV, Samaras K. Obesity is associated with activated and insulin resistant immune cells. Diabetes Metab Res Rev. (2012) 28:447-54. doi: 10.1002/dmrr.2302

27. Huttunen R, Syrjänen J. Obesity and the risk and outcome of infection. Int J Obes. (2013) 37:333-40. doi: 10.1038/ijo.2012.62

28. Sattar N, McInnes IB, McMurray JJV. Obesity is a risk factor for severe COVID-19 infection. Circulation. (2020) 142:4-6. doi: 10.1161/CIRCULATIONAHA.120.047659

29. Dixon AE, Peters U. The effect of obesity on lung function. Expert Rev Respir Med. (2018) 12:755-67. doi: 10.1080/17476348.2018.1506331

30. Saberi M, Woods N-B, de Luca C, Schenk S, Lu JC, Bandyopadhyay $\mathrm{G}$, et al. Hematopoietic cell-specific deletion of toll-like receptor 4 ameliorates hepatic and adipose tissue insulin resistance in highfat-fed mice. Cell Metab. (2009) 10:419-29. doi: 10.1016/j.cmet.2009. 09.006

31. Vitseva OI, Tanriverdi K, Tchkonia TT, Kirkland JL, McDonnell ME, Apovian CM, et al. Inducible toll-like receptor and NF-kappaB regulatory pathway expression in human adipose tissue. Obesity. (2008) 16:9327. doi: 10.1038/oby.2008.25

32. Thomas D, Apovian C. Macrophage functions in lean and obese adipose tissue. Metabolism. (2017) 72:120-43. doi: 10.1016/j.metabol.2017.04.005

33. Karczewski J, Sledzińska E, Baturo A, Jończyk I, Maleszko A, Samborski P, et al. Obesity and inflammation. Eur Cytok Netw. (2018) 29:8394. doi: 10.1684/ecn.2018.0415

34. Chen L, Chen R, Wang H, Liang F. Mechanisms linking inflammation to insulin resistance. Int $J$ Endocrinol. (2015) 2015:508409. doi: 10.1155/2015/508409

35. Cerf ME. Beta cell dysfunction and insulin resistance. Front Endocrinol. (2013) 4:37. doi: 10.3389/fendo.2013.00037

36. Darvall KAL, Sam RC, Silverman SH, Bradbury AW, Adam DJ. Obesity and thrombosis. Eur J Vasc Endovasc Surg. (2007) 33:22333. doi: 10.1016/j.ejvs.2006.10.006

37. Samad F, Ruf W. Inflammation, obesity, and thrombosis. Blood. (2013) 122:3415-22. doi: 10.1182/blood-2013-05-427708

38. Czuprynska J, Arya R. Chapter 27 - obesity and venous thromboembolism. In: Mahmood TA, Arulkumaran S, Chervenak FA, editors. Obesity and Gynecology. 2nd ed. Amsterdam: Elsevier (2020). p. 245-53.

39. Freedman JE, Larson MG, Tanriverdi K, O’Donnell CJ, Morin K, Hakanson AS, et al. Relation of platelet and leukocyte inflammatory transcripts to body mass index in the Framingham heart study. Circulation. (2010) 122:11929. doi: 10.1161/CIRCULATIONAHA.109.928192

40. Blokhin IO, Lentz SR. Mechanisms of thrombosis in obesity. Curr Opin Hematol. (2013) 20:437-44. doi: 10.1097/MOH.0b013e3283634443

41. Samad F, Loskutoff DJ. Tissue distribution and regulation of plasminogen activator inhibitor-1 in obese mice. Mol Med. (1996) 2:568-82. doi: 10.1007/BF03401641

42. Bikdeli B, Madhavan MV, Jimenez D, Chuich T, Dreyfus I, Driggin E, et al. COVID-19 and thrombotic or thromboembolic disease: implications for prevention, antithrombotic therapy, and follow-up: JACC state-of-the-art review. J Am Coll Cardiol. (2020) 75:2950-73. doi: 10.1016/j.jacc.2020.04.031

43. Kass DA, Duggal P, Cingolani O. Obesity could shift severe COVID-19 disease to younger ages. Lancet. (2020) 395:15445. doi: 10.1016/S0140-6736(20)31024-2

44. Stefan N, Birkenfeld AL, Schulze MB, Ludwig DS. Obesity and impaired metabolic health in patients with COVID-19. Nat Rev Endocrinol. (2020) 16:341-2. doi: 10.1038/s41574-020-0364-6

45. Petrakis D, Margină D, Tsarouhas K, Tekos F, Stan M, Nikitovic D, et al. Obesity - a risk factor for increased COVID-19 prevalence, severity and lethality (Review). Mol Med Rep. (2020) 22:9-19. doi: 10.3892/mmr.2020. 11127

46. Zabetakis I, Lordan R, Norton C, Tsoupras A. COVID-19: the inflammation link and the role of nutrition in potential mitigation. Nutrients. (2020) 12:1466. doi: 10.3390/nu120 51466 
47. Ho FK, Celis-Morales CA, Gray SR, Katikireddi SV, Niedzwiedz CL, Hastie C, et al. Modifiable and non-modifiable risk factors for COVID-19: results from UK Biobank. medRxiv. (2020). doi: 10.1101/2020.04.28.20083295

48. Williamson E, Walker AJ, Bhaskaran KJ, Bacon S, Bates C, Morton CE, et al. OpenSAFELY: factors associated with COVID-19-related hospital death in the linked electronic health records of 17 million adult NHS patients. medRxiv. (2020). doi: 10.1101/2020.05.06.20092999

49. Hussain A, Mahawar K, Xia Z, Yang W, El-Hasani S. Obesity and mortality of COVID-19. Meta-analysis. Obes Res Clin Pract. (2020) 14:295300. doi: 10.1016/j.orcp.2020.07.002

50. Rojas-Osornio SA, Cruz-Hernández TR, Drago-Serrano ME, CamposRodríguez R. Immunity to influenza: impact of obesity. Obes Res Clin Pract. (2019) 13:419-29. doi: 10.1016/j.orcp.2019.05.003

51. Vellozo NS, Pereira-Marques ST, Cabral-Piccin MP, Filardy AA, RibeiroGomes FL, Rigoni TS, et al. All-trans retinoic acid promotes an M1- to M2phenotype shift and inhibits macrophage-mediated immunity to leishmania major. Front Immunol. (2017) 8:1560. doi: 10.3389/fimmu.2017.01560

52. Chang H-K, Hou W-S. Retinoic acid modulates interferon- $\gamma$ production by hepatic natural killer $\mathrm{T}$ cells via phosphatase $2 \mathrm{~A}$ and the extracellular signal-regulated kinase pathway. J Interferon Cytok Res. (2015) 35:20012. doi: 10.1089/jir.2014.0098

53. Mucida D, Park Y, Kim G, Turovskaya O, Scott I, Kronenberg M, et al. Reciprocal TH17 and regulatory $\mathrm{T}$ cell differentiation mediated by retinoic acid. Science. (2007) 317:256-60. doi: 10.1126/science.1145697

54. Sinha S, Cheng K, Aldape K, Schiff E, Ruppin E. Systematic cell linebased identification of drugs modifying ACE2 expression. Preprints. (2020). doi: 10.20944/preprints202003.0446.v1

55. Huang Z, Liu Y, Qi G, Brand D, Zheng SG. Role of vitamin A in the immune system. J Clin Med. (2018) 7:258. doi: 10.3390/jcm7090258

56. Carr AC, Maggini S. Vitamin C and immune function. Nutrients. (2017) 9:1211. doi: 10.3390/nu9111211

57. Matheu V, Bäck O, Mondoc E, Issazadeh-Navikas S. Dual effects of vitamin D-induced alteration of $\mathrm{TH} 1 / \mathrm{TH} 2$ cytokine expression: enhancing IgE production and decreasing airway eosinophilia in murine allergic airway disease. J Allergy Clin Immunol. (2003) 112:585-92. doi: 10.1016/S0091-6749(03)01855-4

58. Nishio K, Horie M, Akazawa $Y$, Shichiri $M$, Iwahashi $H$, Hagihara Y, et al. Attenuation of lipopolysaccharide (LPS)-induced cytotoxicity by tocopherols and tocotrienols. Redox Biol. (2013) 1:97-103. doi: 10.1016/j.redox.2012.10.002

59. Hernandez ML, Wagner JG, Kala A, Mills K, Wells HB, Alexis NE, et al. Vitamin E, $\gamma$-tocopherol, reduces airway neutrophil recruitment after inhaled endotoxin challenge in rats and in healthy volunteers. Free Radic Biol Med. (2013) 60:56-62. doi: 10.1016/j.freeradbiomed.2013.02.001

60. Nagai A, Matsumiya H, Hayashi M, Yasui S, Okamoto H, Konno K. Effects of nicotinamide and niacin on bleomycin-induced acute injury and subsequent fibrosis in hamster lungs. Exp Lung Res. (1994) 20:26381. doi: 10.3109/01902149409064387

61. Gharote MA. Role of poly (ADP) ribose polymerase-1 inhibition by nicotinamide as a possible additive treatment to modulate host immune response and prevention of cytokine storm in COVID-19. Indian J Med Sci. (2020) 72:25-8. doi: 10.25259/IJMS_29_2020

62. Tamura J, Kubota K, Murakami H, Sawamura M, Matsushima T, Tamura $\mathrm{T}$, et al. Immunomodulation by vitamin B12: augmentation of CD8+ T lymphocytes and natural killer (NK) cell activity in vitamin B12-deficient patients by methyl-B12 treatment. Clin Exp Immunol. (1999) 116:2832. doi: 10.1046/j.1365-2249.1999.00870.x

63. Kumar V, Jena M. In silico virtual screening-based study of nutraceuticals predicts the therapeutic potentials of folic acid and its derivatives against COVID-19. Res Square. (2020). doi: 10.21203/rs.3.rs-31775/v1

64. Hirmerová J. Homocysteine and venous thromboembolism-Is there any link? Cor et Vasa. (2013) 55:e248-58. doi: 10.1016/j.crvasa.2013.01.007

65. Nelson SM, Lei X, Prabhu KS. Selenium levels affect the IL-4-induced expression of alternative activation markers in murine macrophages. J Nutr. (2011) 141:1754-61. doi: 10.3945/jn.111.141176

66. Kieliszek M, Lipinski B. Selenium supplementation in the prevention of coronavirus infections (COVID-19). Med Hypotheses. (2020) 143:109878. doi: 10.1016/j.mehy.2020.109878
67. Morgan CI, Ledford JR, Zhou P, Page K. Zinc supplementation alters airway inflammation and airway hyperresponsiveness to a common allergen. $J$ Inflamm. (2011) 8:36. doi: 10.1186/1476-9255-8-36

68. Lang CJ, Hansen M, Roscioli E, Jones J, Murgia C, Leigh Ackland M, et al. Dietary zinc mediates inflammation and protects against wasting and metabolic derangement caused by sustained cigarette smoke exposure in mice. Biometals. (2011) 24:23-39. doi: 10.1007/s10534-010-9370-9

69. Prasad AS, Bao B, Beck FWJ, Sarkar FH. Zinc-suppressed inflammatory cytokines by induction of A20-mediated inhibition of nuclear factor-кB. Nutrition. (2011) 27:816-23. doi: 10.1016/j.nut.2010.08.010

70. Beck FW, Prasad AS, Kaplan J, Fitzgerald JT, Brewer GJ. Changes in cytokine production and $\mathrm{T}$ cell subpopulations in experimentally induced zinc-deficient humans. Am J Physiol Endocrinol Metab. (1997) 272:E10027. doi: 10.1152/ajpendo.1997.272.6.E1002

71. Prasad AS. Effects of zinc deficiency on Th1 and Th2 cytokine shifts. J Infect Dis. (2000) 182:S62-8. doi: 10.1086/315916

72. Speth R, Carrera E, Jean-Baptiste M, Joachim A, Linares A. Concentration-dependent effects of zinc on angiotensinconverting enzyme-2 activity (1067.4). FASEB J. (2014) 28:1067.4. doi: 10.1096/fasebj.28.1_supplement.1067.4

73. Skalny AV, Rink L, Ajsuvakova OP, Aschner M, Gritsenko VA, Alekseenko SI, et al. Zinc and respiratory tract infections: perspectives for COVID-19 (Review). Int J Mol Med. (2020) 46:17-26. doi: 10.3892/ijmm.2020.4575

74. Adamcakova-Dodd A, Monick MM, Powers LS, Gibson-Corley KN, Thorne PS. Effects of prenatal inhalation exposure to copper nanoparticles on murine dams and offspring. Particle Fibre Toxicol. (2015) 12:30. doi: 10.1186/s12989-015-0105-5

75. Muñoz C, López M, Olivares M, Pizarro F, Arredondo M, Araya M. Differential response of interleukin-2 production to chronic copper supplementation in healthy humans. Eur Cytok Netw. (2005) 16:261-5.

76. Gaetke LM, Chow-Johnson HS, Chow CK. Copper: toxicological relevance and mechanisms. Arch Toxicol. (2014) 88:192938. doi: 10.1007/s00204-014-1355-y

77. Li X, Li L, Tao L, Zheng H, Sun M, Chen Y, et al. Magnesium sulfate prophylaxis attenuates the postpartum effects of preeclampsia by promoting M2 macrophage polarization. Hypertens Res. (2020) doi: 10.1038/s41440-020-0511-4. [Epub ahead of print].

78. Li W, Wu X, Yu J, Ma C, Zhuang P, Zeng J, et al. Magnesium sulfate attenuates lipopolysaccharides-induced acute lung injury in mice. Chin J Physiol. (2019) 62:203-9. doi: 10.4103/CJP.CJP_48_19

79. Van de Graaf RC, Hofstra L. Obesity and covid-19: the role of the food industry. BMJ. (2020) 370:m2813. doi: 10.1136/bmj.m2813

80. Jia $\mathrm{X}$, Yin $\mathrm{C}$, Lu S, Chen Y, Liu Q, Bai J, et al. Two things about COVID-19 might need attention. Preprints. (2020). doi: 10.20944/preprints202002.0315.v1

81. Kruglikov IL, Scherer PE. The role of adipocytes and adipocyte-like cells in the severity of COVID-19 infections. Obesity. (2020) 28:118790. doi: 10.1002/oby.22856

82. Mendy A, Gopal R, Alcorn JF, Forno E. Reduced mortality from lower respiratory tract disease in adult diabetic patients treated with metformin. Respirology. (2019) 24:646-51. doi: 10.1111/resp.13486

83. Hoffmann M, Kleine-Weber H, Schroeder S, Krüger N, Herrler T, Erichsen $\mathrm{S}$, et al. SARS-CoV-2 cell entry depends on ACE2 and TMPRSS2 and is blocked by a clinically proven protease inhibitor. Cell. (2020) 181:27180.e8. doi: 10.1016/j.cell.2020.02.052

84. Liu Z, Xiao X, Wei X, Li J, Yang J, Tan H, et al. Composition and divergence of coronavirus spike proteins and host ACE2 receptors predict potential intermediate hosts of SARS-CoV-2. J Med Virol. (2020) 92:595601. doi: 10.1002/jmv. 25726

85. Bassendine MF, Bridge SH, McCaughan GW, Gorrell MD. COVID-19 and comorbidities: a role for dipeptidyl peptidase 4 (DPP4) in disease severity? J Diabetes. (2020) 12:649-58. doi: 10.1111/1753-0407.13052

86. Patel VB, Mori J, McLean BA, Basu R, Das SK, Ramprasath T, et al. ACE2 deficiency worsens epicardial adipose tissue inflammation and cardiac dysfunction in response to diet-induced obesity. Diabetes. (2016) 65:85. doi: 10.2337/db15-0399

87. Cure E, Cumhur Cure M. Angiotensin-converting enzyme inhibitors and angiotensin receptor blockers may be harmful in patients with diabetes 
during COVID-19 pandemic. Diabetes Metab Syndr Clin Res Rev. (2020) 14:349-50. doi: 10.1016/j.dsx.2020.04.019

88. Liu F, Long X, Zhang B, Zhang W, Chen X, Zhang Z. ACE2 expression in pancreas may cause pancreatic damage after SARS-CoV-2 infection. Clin Gastroenterol Hepatol. (2020) 18:2128-30.e2. doi: 10.1101/2020.02.28.20029181

89. Correa-Rodríguez M, Luis Gómez-Urquiza J, Medina-Martínez I, GonzálezJiménez E, Schmidt-RioValle J, Rueda-Medina B. Low intakes of vitamins C and $\mathrm{A}$ are associated with obesity in early adulthood. Int J Vitamin Nutr Res. (2020) 1-10. doi: 10.1024/0300-9831/a000661

90. Wintergerst ES, Maggini S, Hornig DH. Contribution of selected vitamins and trace elements to immune function. Ann Nutr Metab. (2007) 51:30123. doi: $10.1159 / 000107673$

91. West CE, Sijtsma SR, Kouwenhoven B, Rombout JHWM, van der Zijpp AJ. Epithelia-damaging virus infections affect vitamin a status in chickens. J Nutr. (1992) 122:333-9. doi: 10.1093/jn/122.2.333

92. Zhang L, Liu Y. Potential interventions for novel coronavirus in China: a systematic review. J Med Virol. (2020) 92:479-90. doi: 10.1002/jmv.25707

93. Ross AC, Stephensen CB. Vitamin A and retinoids in antiviral responses. FASEB J. (1996) 10:979-85. doi: 10.1096/fasebj.10.9.8801180

94. Trasino SE. A role for retinoids in the treatment of covid-19? Clin Exp Pharmacol Physiol. (2020) 47:1765-7. doi: 10.1111/1440-1681.13354

95. Li G, He X, Zhang L, Ran Q, Wang J, Xiong A, et al. Assessing ACE2 expression patterns in lung tissues in the pathogenesis of COVID-19. J Autoimmunity. (2020) 2020:102463. doi: 10.1016/j.jaut.2020.102463

96. Zhou TB, Ou C, Rong L, Drummen GP. Effect of all-trans retinoic acid treatment on prohibitin and renin-angiotensinaldosterone system expression in hypoxia-induced renal tubular epithelial cell injury. J Renin Angiotensin Aldosterone Syst. (2014) 15:243-9. doi: $10.1177 / 1470320314542727$

97. Timoneda J, Rodríguez-Fernández L, Zaragozá R, Marín MP, Cabezuelo MT, Torres L, et al. Vitamin A deficiency and the lung. Nutrients. (2018) 10:1132. doi: 10.3390/nu10091132

98. Penkert RR, Cortez V, Karlsson EA, Livingston B, Surman SL, Li Y, et al. Vitamin A corrects tissue deficits in diet-induced obese mice and reduces influenza infection after vaccination and challenge. Obesity. (2020) 28:16316. doi: $10.1002 /$ oby. 22929

99. Trasino SE, Tang X-H, Jessurun J, Gudas LJ. Obesity leads to tissue, but not serum vitamin A deficiency. Sci Rep. (2015) 5:15893. doi: 10.1038/srep15893

100. Garcia OP. Effect of vitamin A deficiency on the immune response in obesity. Proc Nutr Soc. (2012) 71:290-7. doi: 10.1017/S0029665112000079

101. Jeyakumar SM, Vajreswari A, Giridharan NV. Chronic dietary vitamin A supplementation regulates obesity in an obese mutant WNIN/Ob rat model. Obesity. (2006) 14:52-9. doi: 10.1038/oby.2006.7

102. Hemilä H. Vitamin C and infections. Nutrients. (2017) 9:339. doi: 10.3390/nu9040339

103. Hemilä H. Vitamin $\mathrm{C}$ supplementation and respiratory infections: a systematic review. Military Med. (2004) 169:9205. doi: 10.7205/MILMED.169.11.920

104. Kim Y, Kim H, Bae S, Choi J, Lim SY, Lee N, et al. Vitamin C is an essential factor on the anti-viral immune responses through the production of interferon- $\alpha / \beta$ at the initial stage of influenza A virus (H3N2) infection. Immune Netw. (2013) 13:70-4. doi: 10.4110/in.2013.13.2.70

105. Trinchieri G. Type I interferon: friend or foe? J Exp Med. (2010) 207:205363. doi: $10.1084 /$ jem. 20101664

106. Marik PE. Hydrocortisone, ascorbic acid and Thiamine (HAT Therapy) for the treatment of sepsis. Focus on ascorbic acid. Nutrients. (2018) 10:1762. doi: $10.3390 /$ nu10111762

107. Garcia-Diaz DF, Lopez-Legarrea P, Quintero P, Martinez JA. Vitamin C in the treatment and/or prevention of obesity. J Nutr Sci Vitaminol. (2014) 60:367-79. doi: 10.3177/jnsv.60.367

108. Vorilhon P, Arpajou B, Vaillant Roussel H, Merlin É, Pereira B, Cabaillot A. Efficacy of vitamin $C$ for the prevention and treatment of upper respiratory tract infection. A meta-analysis in children. Eur J Clin Pharmacol. (2019) 75:303-11. doi: 10.1007/s00228-018-2601-7

109. Fowler AA, 3rd, Syed AA, Knowlson S, Sculthorpe R, Farthing D, deWilde C, et al. Phase I safety trial of intravenous ascorbic acid in patients with severe sepsis. J Transl Med. (2014) 12:32. doi: 10.1186/1479-5876-12-32
110. Fisher BJ, Seropian IM, Kraskauskas D, Thakkar JN, Voelkel NF, Fowler AA, et al. Ascorbic acid attenuates lipopolysaccharide-induced acute lung injury. Crit Care Med. (2011) 39:1454-60. doi: 10.1097/CCM.0b013e3182120cb8

111. Mah E, Matos MD, Kawiecki D, Ballard K, Guo Y, Volek JS, et al. Vitamin C status is related to proinflammatory responses and impaired vascular endothelial function in healthy, college-aged lean and obese men. J Am Diet Assoc. (2011) 111:737-43. doi: 10.1016/j.jada.2011.02.003

112. Ellulu MS, Rahmat A, Patimah I, Khaza'ai H, Abed Y. Effect of vitamin $\mathrm{C}$ on inflammation and metabolic markers in hypertensive and/or diabetic obese adults: a randomized controlled trial. Drug Des Devel Ther. (2015) 9:3405-12. doi: 10.2147/DDDT.S83144

113. Furuya A, Uozaki M, Yamasaki H, Arakawa T, Arita M, Koyama AH. Antiviral effects of ascorbic and dehydroascorbic acids in vitro. Int $\mathrm{J} \mathrm{Mol}$ Med. (2008) 22:541-5. doi: 10.3892/ijmm_00000053

114. Cai Y, Li Y-F, Tang L-P, Tsoi B, Chen M, Chen H, et al. A new mechanism of vitamin $C$ effects on $A / F M / 1 / 47(\mathrm{H} 1 \mathrm{~N} 1)$ virusinduced pneumonia in restraint-stressed mice. Biomed Res Int. (2015) 2015:675149. doi: 10.1155/2015/675149

115. Peng Z. Vitamin C Infusion for the Treatment of Severe 2019-nCoV Infected Pneumonia. (2020). Available online at: https://clinicaltrials.gov/ct2/show/ NCT04264533 (accessed June 1, 2020).

116. Erol A. High-Dose Intravenous Vitamin C Treatment for COVID-19. (2020). Available online at: https://osf.io/p7ex8/ (accessed June 5, 2020).

117. Ginde AA, Mansbach JM, Camargo CA Jr. Association between serum 25hydroxyvitamin D level and upper respiratory tract infection in the Third National health and nutrition examination survey. Arch Intern Med. (2009) 169:384-90. doi: 10.1001/archinternmed.2008.560

118. Park JM, Park CY, Han SN. High fat diet-Induced obesity alters vitamin D metabolizing enzyme expression in mice. BioFactors. (2015) 41:17582. doi: 10.1002/biof.1211

119. Lin C-H, Liao W-L, Wu C-C, Shaw H-M, Hsu W-L, Lu Y-C, et al. Nutritional status of obese Taiwanese before bariatric-metabolic surgery and their serum 25-hydroxyvitamin D concentrations for maximal suppression of parathyroid hormone. Obes Surg. (2020) 10:3940-6. doi: 10.1007/s11695-020-04759-y

120. Craveiro V, Cabral M, Araujo J, Falcao H, Guimaraes JT, Ramos E. Association of serum 25-hydroxyvitamin D concentration with pulmonary function in young adults. Nutrients. (2018) 10:1728. doi: 10.3390/nu10111728

121. Greiller CL, Martineau AR. Modulation of the immune response to respiratory viruses by vitamin D. Nutrients. (2015) 7:4240-70. doi: 10.3390/nu7064240

122. Gruber-Bzura BM. Vitamin D and influenza-prevention or therapy? Int J Mol Sci. (2018) 19:2419. doi: 10.3390/ijms19082419

123. Kohlmeier M. Avoidance of vitamin D deficiency to slow the COVID-19 pandemic. BMJ Nutr Prev Health. (2020) 3:bmjnph-2020000096. doi: 10.1136/bmjnph-2020-000096

124. Lanham-New SA, Webb AR, Cashman KD, Buttriss JL, Fallowfield JL, Masud T, et al. Vitamin D and SARS-CoV-2 virus/COVID-19 disease. BMJ Nutr Prev Health. (2020) 3:bmjnph-2020-000089. doi: 10.1136/bmjnph-2020-000089

125. Hughes DA, Norton R. Vitamin D and respiratory health. Clin Exp Immunol. (2009) 158:20-5. doi: 10.1111/j.1365-2249.2009.04001.x

126. Zdrenghea MT, Makrinioti H, Bagacean C, Bush A, Johnston SL, Stanciu LA. Vitamin D modulation of innate immune responses to respiratory viral infections. Rev Med Virol. (2017) 27:e1909. doi: 10.1002/rmv.1909

127. Chen S, Sims GP, Chen XX, Gu YY, Chen S, Lipsky PE. Modulatory effects of 1,25-dihydroxyvitamin D3 on human B cell differentiation. J ImmunoL. (2007) 179:1634-47. doi: 10.4049/jimmunol.179.3.1634

128. Cantorna MT, Snyder L, Lin Y-D, Yang L. Vitamin D and $1,25(\mathrm{OH}) 2 \mathrm{D}$ regulation of T cells. Nutrients. (2015) 7:3011-21. doi: 10.3390/nu7043011

129. Almerighi C, Sinistro A, Cavazza A, Ciaprini C, Rocchi G, Bergamini A. 1Alpha,25-dihydroxyvitamin D3 inhibits CD40L-induced pro-inflammatory and immunomodulatory activity in human monocytes. Cytokine. (2009) 45:190-7. doi: 10.1016/j.cyto.2008.12.009

130. Aranow C. Vitamin D and the immune system. J Investig Med. (2011) 59:881-6. doi: 10.2310/JIM.0b013e31821b8755

131. Glaab E, Ruepp A, Montrone C, Fobo G, Ostaszewski M. The Role of the Interaction Between the SARS-CoV-2 Spike Protein and the Renin-Angiotensin 
Pathway, in Particular Human ACE2 in Pulmonary Blood Pressure Regulation. (2020). Available online at: https://fairdomhub.org/models/709 (accessed June 25, 2020).

132. Rafiullah M. Can a combination of AT1R antagonist and Vitamin D treat the lung complication of COVID-19? Am J Med Sci. (2020) 360:33841. doi: 10.1016/j.amjms.2020.07.018

133. Bergman P, Lindh AU, Björkhem-Bergman L, Lindh JD. Vitamin $\mathrm{D}$ and respiratory tract infections: a systematic review and metaanalysis of randomized controlled trials. PLoS ONE. (2013) 8:e65835. doi: 10.1371/journal.pone.0065835

134. Hastie CE, Mackay DF, Ho F, Celis-Morales CA, Katikireddi SV, Niedzwiedz CL, et al. Vitamin D concentrations and COVID-19 infection in UK Biobank. Diabetes Metab Syndr Clin Res Rev. (2020) 14:5615. doi: 10.1016/j.dsx.2020.04.050

135. Moriguchi S, Muraga M. Vitamin E and immunity. Vitamins Hormones. (2000) 59:305-36. doi: 10.1016/S0083-6729(00)59011-6

136. Hybertson BM, Leff JA, Beehler CJ, Barry PC, Repine JE. Effect of vitamin E deficiency and supercritical fluid aerosolized vitamin E supplementation on interleukin-1-induced oxidative lung injury in rats. Free Radic Biol Med. (1995) 18:537-42. doi: 10.1016/0891-5849(94)00180-R

137. Yamaoka S, Kim H-S, Ogihara T, Oue S, Takitani K, Yoshida Y, et al. Severe Vitamin E deficiency exacerbates acute hyperoxic lung injury associated with increased oxidative stress and inflammation. Free Radic Res. (2008) 42:602-12. doi: 10.1080/10715760802189864

138. Hanson C, Lyden E, Furtado J, Campos H, Sparrow D, Vokonas P, et al. Serum tocopherol levels and vitamin E intake are associated with lung function in the normative aging study. Clin Nutr. (2016) 35:16974. doi: 10.1016/j.clnu.2015.01.020

139. Agler AH, Kurth T, Gaziano JM, Buring JE, Cassano PA. Randomised vitamin $\mathrm{E}$ supplementation and risk of chronic lung disease in the Women's Health Study. Thorax. (2011) 66:320-5. doi: 10.1136/thx.2010.155028

140. Meydani SN, Leka LS, Fine BC, Dallal GE, Keusch GT, Singh MF, et al. Vitamin $\mathrm{E}$ and respiratory tract infections in elderly nursing home residents: a randomized controlled trial. JAMA. (2004) 292:82836. doi: 10.1001/jama.292.7.828

141. Turski WA, Wnorowski A, Turski GN, Turski CA, Turski L. AhR and IDO1 in pathogenesis of Covid-19 and the "systemic AhR activation syndrome:" translational review and therapeutic perspectives. Restor Neurol Neurosci. (2020) 38, 343-54. doi: 10.3233/RNN-201042

142. Belghasem M, Roth D, Richards S, Napolene MA, Walker J, Yin W, et al. Metabolites in a mouse cancer model enhance venous thrombogenicity through the aryl hydrocarbon receptor-tissue factor axis. Blood. (2019) 134:2399-413. doi: 10.1182/blood.2019001675

143. Weidenbusch M, Rodler S, Song S, Romoli S, Marschner Julian A, Kraft F, et al. Gene expression profiling of the Notch-AhR-IL22 axis at homeostasis and in response to tissue injury. Biosci Rep. (2017) 37:BSR20170099. doi: 10.1042/BSR20170099

144. Kerley-Hamilton JS, Trask HW, Ridley CJA, Dufour E, Ringelberg CS, Nurinova $\mathrm{N}$, et al. Obesity is mediated by differential aryl hydrocarbon receptor signaling in mice fed a Western diet. Environ Health Perspect. (2012) 120:1252-9. doi: 10.1289/ehp.1205003

145. Moyer BJ, Rojas IY, Kerley-Hamilton JS, Hazlett HF, Nemani KV, Trask HW, et al. Inhibition of the aryl hydrocarbon receptor prevents Western diet-induced obesity. Model for AHR activation by kynurenine via oxidizedLDL, TLR2/4, TGF $\beta$, and IDO1. Toxicol Appl Pharmacol. (2016) 300:1324. doi: 10.1016/j.taap.2016.03.011

146. Kulanuwat S, Tungtrongchitr R, Billington D, Davies IG. Prevalence of plasma small dense LDL is increased in obesity in a Thai population. Lipids Health Dis. (2015) 14:30. doi: 10.1186/s12944-015-0034-1

147. McMillan BJ, Bradfield CA. The aryl hydrocarbon receptor is activated by modified low-density lipoprotein. Proc Natl Acad Sci USA. (2007) 104:14127. doi: 10.1073/pnas.0607296104

148. Takami M, Fujimaki K, Nishimura MI, Iwashima M. Cutting edge: AhR is a molecular target of calcitriol in human T cells. J Immunol. (2015) 195:2520. doi: 10.4049/jimmunol.1500344

149. Stapelberg M, Zobalova R, Nguyen MN, Walker $T$, Stantic M, Goodwin J, et al. Indoleamine-2,3-dioxygenase elevated in tumor-initiating cells is suppressed by mitocans. Free Radic
Biol Med. (2014) 67:41-50. doi: 10.1016/j.freeradbiomed.2013. 10.003

150. Hong G, Zheng D, Zhang L, Ni R, Wang G, Fan G-C, et al. Administration of nicotinamide riboside prevents oxidative stress and organ injury in sepsis. Free Radic Biol Med. (2018) 123:125-37. doi: 10.1016/j.freeradbiomed.2018.05.073

151. Zingarelli B, Salzman AL, Szabó C. Protective effects of nicotinamide against nitric oxide-mediated delayed vascular failure in endotoxic shock: potential involvement of polyADP ribosyl synthetase. Shock. (1996) 5:25864. doi: 10.1097/00024382-199604000-00005

152. Yamaguchi S, Yoshino J. Adipose tissue $\mathrm{NAD}(+)$ biology in obesity and insulin resistance: from mechanism to therapy. Bioessays. (2017) 39:10.1002/bies.201600227. doi: 10.1002/bies.201600227

153. Canto C, Houtkooper RH, Pirinen E, Youn DY, Oosterveer MH, Cen Y, et al. The $\mathrm{NAD}(+)$ precursor nicotinamide riboside enhances oxidative metabolism and protects against high-fat diet-induced obesity. Cell Metab. (2012) 15:838-47. doi: 10.1016/j.cmet.2012.04.022

154. Fimognari FL, Di Simone S, Corsonello A, Pastorelli R, Sampietro F, Loffredo L, et al. Poor vitamin B6 status: a novel potential thrombotic factor in chronic obstructive pulmonary disease. Nutr Metab Cardiovasc Dis. (2010) 20:e17-8. doi: 10.1016/j.numecd.2010.06.008

155. Shan M-R, Zhou S-N, Fu C-N, Song J-W, Wang X-Q, Bai W-W, et al. Vitamin B6 inhibits macrophage activation to prevent lipopolysaccharideinduced acute pneumonia in mice. J Cell Mol Med. (2020) 24:313948. doi: $10.1111 / \mathrm{jcmm} .14983$

156. Desbarats J. Pyridoxal 5'-phosphate to mitigate immune dysregulation and coagulopathy in COVID-19. Preprints. (2020). doi: 10.20944/preprints202005.0144.v1

157. Menezes RR, Godin AM, Rodrigues FF, Coura GME, Melo ISF, Brito AMS, et al. Thiamine and riboflavin inhibit production of cytokines and increase the anti-inflammatory activity of a corticosteroid in a chronic model of inflammation induced by complete Freund's adjuvant. Pharmacol Rep. (2017) 69:1036-43. doi: 10.1016/j.pharep.2017.04.011

158. Yam D, Aluisio AR, Perera SM, Peters JL, Cho DK, Kennedy SB, et al. Association between multivitamin supplementation and mortality among patients with Ebola virus disease: an international multisite cohort study. Afr J Emerg Med. (2020) 10:23-9. d 0.1016/j.afjem.2019.11.001

159. Sheybani Z, Dokoohaki MH, Negahdaripour M, Dehdashti M, Zolghadr $H$, Moghadami $M$, et al. The role of folic acid in the management of respiratory disease caused by COVID-19. ChemRxiv. (2020). doi: 10.26434/chemrxiv.12034980

160. Serseg T, Benarous K, Yousfi M. Hispidin and lepidine E: two natural compounds and folic acid as potential inhibitors of 2019-novel coronavirus main protease (2019-nCoVMpro), molecular docking and SAR study. Curr Comput Aided Drug Des. (2020) 16:1-11. doi: $10.2174 / 1573409916666200422075440$

161. Haloul M, Vinjamuri SJ, Naquiallah D, Mirza MI, Qureshi M, Hassan C, et al. Hyperhomocysteinemia and low folate and vitamin B12 are associated with vascular dysfunction and impaired nitric oxide sensitivity in morbidly obese patients. Nutrients. (2020) 12:2014. doi: 10.3390/nu12072014

162. Nielsen FH. Magnesium, inflammation, and obesity in chronic disease. Nutr Rev. (2010) 68:333-40. doi: 10.1111/j.1753-4887.2010.00293.x

163. Costello RB, Elin RJ, Rosanoff A, Wallace TC, Guerrero-Romero F, Hruby A, et al. Perspective: the case for an evidence-based reference interval for serum magnesium: the time has come. Adv Nutr. (2016) 7:97793. doi: 10.3945/an.116.012765

164. Mathew R, Altura BM. The role of magnesium in lung diseases: asthma, allergy and pulmonary hypertension. Magnes Trace Elem. (1991) 10:220-8.

165. Tan CW, Ho LP, Kalimuddin S, Cherng BPZ, Teh YE, Thien SY, et al. A cohort study to evaluate the effect of combination Vitamin D, Magnesium and Vitamin B12 (DMB) on progression to severe outcome in older COVID-19 patients. medRxiv. (2020) 2020.06.01.20112334. doi: 10.1101/2020.06.01.20112334

166. Wallace TC. Combating COVID-19 and building immune resilience: a potential role for magnesium nutrition? J Am Coll Nutr. (2020) 10:19. doi: $10.1080 / 07315724.2020 .1785971$

167. Parichehr P, Guitti P. Magnesium sulfate: a potential adjuvant treatment on COVID-19. Adv J Emerg Med. (2020) doi: 10.22114/ajem.v0i0.508 
168. Rayman MP. Selenium and human health. Lancet. (2012) 379:125668. doi: 10.1016/S0140-6736(11)61452-9

169. Hoffmann PR, Berry MJ. The influence of selenium on immune responses. Mol Nutr Food Res. (2008) 52:1273-80. doi: 10.1002/mnfr.200700330

170. Baum MK, Shor-Posner G, Lai S, Zhang G, Lai H, Fletcher MA, et al. High risk of HIV-related mortality is associated with selenium deficiency. J Acqu Immune Def Syndr Hum Retrovirol. (1997) 15:3704. doi: 10.1097/00042560-199708150-00007

171. Beck MA, Levander OA, Handy J. Selenium deficiency and viral infection. $J$ Nutr. (2003) 133:1463-7S. doi: 10.1093/jn/133.5.1463S

172. Steinbrenner H, Al-Quraishy S, Dkhil MA, Wunderlich F, Sies H. Dietary selenium in adjuvant therapy of viral and bacterial infections. Adv Nutr. (2015) 6:73-82. doi: 10.3945/an.114.007575

173. Hoffmann FW, Hashimoto AC, Shafer LA, Dow S, Berry MJ, Hoffmann PR. Dietary selenium modulates activation and differentiation of CD4+ T cells in mice through a mechanism involving cellular free thiols. J Nutr. (2010) 140:1155-61. doi: 10.3945/jn.109.120725

174. Zhang J, Taylor EW, Bennett K, Saad R, Rayman MP. Association between regional selenium status and reported outcome of COVID-19 cases in China. Am J Clin Nutr. (2020) 111:1297-9. doi: 10.1093/ajcn/nqaa095

175. Fakhrolmobasheri M, Nasr-Esfahany Z, Khanahmad H, Zeinalian M. Selenium supplementation can relieve the clinical complications of COVID-19 and other similar viral infections. Int J Vitam Nutr Res. (2020). doi: 10.1024/0300-9831/a000663. [Epub ahead of print].

176. Mahmoodpoor A, Hamishehkar H, Shadvar K, Ostadi Z, Sanaie S, Saghaleini $\mathrm{SH}$, et al. The effect of intravenous selenium on oxidative stress in critically Ill patients with acute respiratory distress syndrome. Immunol Invest. (2019) 48:147-59. doi: 10.1080/08820139.2018.1496098

177. Wang L, Jing J, Yan H, Tang J, Jia G, Liu G, et al. Selenium pretreatment alleviated LPS-induced immunological stress via upregulation of several selenoprotein encoding genes in murine RAW264.7 cells. Biol Trace Elem Res. (2018) 186:505-13. doi: 10.1007/s12011-018-1333-y

178. Tinkov AA, Ajsuvakova OP, Filippini T, Zhou JC, Lei XG, Gatiatulina ER, et al. Selenium and selenoproteins in adipose tissue physiology and obesity. Biomolecules. (2020) 10:658. doi: 10.3390/biom10040658

179. Moghaddam A, Heller RA, Sun Q, Seelig J, Cherkezov A, Seibert L, et al. Selenium deficiency is associated with mortality risk from COVID-19. Nutrients. (2020) 12:2098. doi: 10.3390/nu12072098

180. Prasad AS. Zinc: role in immunity, oxidative stress and chronic inflammation. Curr Opin Clini Nutr Metab Care. (2009) 12:646-52. doi: 10.1097/MCO.0b013e3283312956

181. Koch J, Neal EA, Schlott MJ, Garcia-Shelton YL, Chan MF, Weaver KE, et al. Zinc levels and infections in hospitalized patients with AIDS. Nutrition. (1996) 12:515-8. doi: 10.1016/S0899-9007(96)00173-6

182. Iddir M, Brito A, Dingeo G, Fernandez Del Campo SS, Samouda H, La Frano $\mathrm{MR}$, et al. Strengthening the immune system and reducing inflammation and oxidative stress through diet and nutrition: considerations during the COVID-19 crisis. Nutrients. (2020) 12:1562. doi: 10.3390/nu12061562

183. Razzaque M. COVID-19 pandemic: can maintaining optimal zinc balance enhance host resistance? Preprints. (2020). doi: 10.20944/preprints202004.0006.v1

184. Mossad SB, Macknin ML, Medendorp SV, Mason P. Zinc gluconate lozenges for treating the common cold. A randomized, double-blind, placebo-controlled study. Ann Int Med. (1996) 125:81-8. doi: 10.7326/0003-4819-125-2-199607150-00001

185. Truong-Tran AQ, Carter J, Ruffin R, Zalewski PD. New insights into the role of zinc in the respiratory epithelium. Immunol Cell Biol. (2001) 79:1707. doi: 10.1046/j.1440-1711.2001.00986.x

186. Roscioli E, Jersmann HP, Lester S, Badiei A, Fon A, Zalewski P, et al. Zinc deficiency as a codeterminant for airway epithelial barrier dysfunction in an ex vivo model of COPD. Int J Chron Obstruct Pulmon Dis. (2017) 12:3503-10. doi: 10.2147/COPD.S149589

187. Suara RO, Crowe JE Jr. Effect of zinc salts on respiratory syncytial virus replication. Antimicrob Agents Chemother. (2004) 48:783-90. doi: 10.1128/AAC.48.3.783-790.2004

188. Xue J, Moyer A, Peng B, Wu J, Hannafon BN, Ding WQ. Chloroquine is a zinc ionophore. PLoS ONE. (2014) 9:e109180. doi: 10.1371/journal.pone.0109180
189. Wang $M$, Cao $R$, Zhang $L$, Yang $X$, Liu $J$, Xu $M$, et al. Remdesivir and chloroquine effectively inhibit the recently emerged novel coronavirus $(2019-\mathrm{nCoV})$ in vitro. Cell Res. (2020) 30:269-71. doi: 10.1038/s41422-020-0282-0

190. Finzi E. Treatment of SARS-CoV-2 with high dose oral zinc salts: a report on four patients. Int J Infect Dis. (2020) 99:307-9. doi: 10.1016/j.ijid.2020.06.006

191. Hemilä H, Chalker E. Zinc for preventing and treating the common cold. Cochrane Database Syst Rev. (2017) 2017:CD012808. doi: 10.1002/14651858.CD012808

192. Read SA, Obeid S, Ahlenstiel C, Ahlenstiel G. The role of zinc in antiviral immunity. Adv Nutr. (2019) 10:696-710. doi: 10.1093/advances/nmz013

193. Dagdag RP, Burkhead JL, Bortz E. Influenza versus host: the role of novel copper-related host factors in antiviral immunity. FASEB J. (2020) 34:1. doi: 10.1096/fasebj.2020.34.s1.06545

194. Minoshima M, Lu Y, Kimura T, Nakano R, Ishiguro $H$, Kubota Y, et al. Comparison of the antiviral effect of solidstate copper and silver compounds. J Hazard Mater. (2016) 312:1-7. doi: 10.1016/j.jhazmat.2016.03.023

195. Ishida T. Antiviral activities of $\mathrm{Cu} 2+$ ions in viral prevention, replication, RNA degradation, and for antiviral efficacies of lytic virus, ROS-mediated virus, copper chelation. World Sci News. (2018) 99:148-68. Available online at: www.worldscientificnews.com

196. Han M, Lin Z, Zhang Y. The alteration of copper homeostasis in inflammation induced by lipopolysaccharides. Biol Trace Elem Res. (2013) 154:268-74. doi: 10.1007/s12011-013-9725-5

197. Percival SS. Copper and immunity. Am J Clin Nutr. (1998) 67:10648S. doi: 10.1093/ajcn/67.5.1064S

198. Li C, Li Y, Ding C. The role of copper homeostasis at the hostpathogen axis: from bacteria to fungi. Int J Mol Sci. (2019) 20:175. doi: 10.3390/ijms20010175

199. Liu L, Geng X, McDermott J, Shen J, Corbin C, Xuan S, et al. Copper deficiency in the lungs of TNF- $\alpha$ transgenic mice. Front Physiol. (2016) 7:234. doi: 10.3389/fphys.2016.00234

200. Bonham M, O'Connor JM, Hannigan BM, Strain JJ. The immune system as a physiological indicator of marginal copper status? Br J Nutr. (2002) 87:393-403. doi: 10.1079/BJN2002558

201. Raha S, Mallick R, Basak S, Duttaroy AK. Is copper beneficial for COVID-19 patients? Med Hypotheses. (2020) 142:109814. doi: 10.1016/j.mehy.2020.109814

202. Sagripanti JL, Routson LB, Lytle CD. Virus inactivation by copper or iron ions alone and in the presence of peroxide. Appl Environ Microbiol. (1993) 59:4374-6. doi: 10.1128/AEM.59.12.4374-4376.1993

203. Kampf G, Todt D, Pfaender S, Steinmann E. Persistence of coronaviruses on inanimate surfaces and its inactivation with biocidal agents. J Hosp Infect. (2020) 104:246-51. doi: 10.1016/j.jhin.2020.01.022

204. van Doremalen N, Bushmaker T, Morris DH, Holbrook MG, Gamble A, Williamson BN, et al. Aerosol and surface stability of SARS-CoV2 as compared with SARS-CoV-1. N Engl J Med. (2020) 382:15647. doi: 10.1056/NEJMc2004973

205. González-Gallego J, García-Mediavilla MV, Sánchez-Campos S, Tuñón MJ. Chapter 32 - anti-inflammatory and immunomodulatory properties of dietary flavonoids. In: Watson RR, Preedy VR, Zibadi S, editors. Polyphenols in Human Health and Disease. San Diego, CA: Academic Press (2014). p. 435-52.

206. Kawser Hossain M, Abdal Dayem A, Han J, Yin Y, Kim K, Kumar Saha S, et al. Molecular mechanisms of the anti-obesity and anti-diabetic properties of flavonoids. Int J Mol Sci. (2016) 17:569. doi: 10.3390/ijms17040569

207. Pan MH, Lai CS, Ho CT. Anti-inflammatory activity of natural dietary flavonoids. Food Funct. (2010) 1:15-31. doi: 10.1039/c0fo00103a

208. Vernarelli JA, Lambert JD. Flavonoid intake is inversely associated with obesity and C-reactive protein, a marker for inflammation, in US adults. Nutr Diabetes. (2017) 7:e276. doi: 10.1038/nutd.2017.22

209. Geraets L, Haegens A, Brauers K, Haydock JA, Vernooy JHJ, Wouters EFM, et al. Inhibition of LPS-induced pulmonary inflammation by specific flavonoids. Biochem Biophys Res Commun. (2009) 382:598603. doi: 10.1016/j.bbrc.2009.03.071

210. Lago JHG, Toledo-Arruda AC, Mernak M, Barrosa KH, Martins MA, Tibério IFLC, et al. Structure-activity association of flavonoids in 
lung diseases. Molecules. (2014) 19:3570-95. doi: 10.3390/molecules190 33570

211. Vazhappilly CG, Ansari SA, Al-Jaleeli R, Al-Azawi AM, Ramadan WS, Menon V, et al. Role of flavonoids in thrombotic, cardiovascular, and inflammatory diseases. Inflammopharmacology. (2019) 27:863-9. doi: 10.1007/s10787-019-00612-6

212. Zakaryan H, Arabyan E, Oo A, Zandi K. Flavonoids: promising natural compounds against viral infections. Arch Virol. (2017) 162:253951. doi: 10.1007/s00705-017-3417-y

213. Somerville VS, Braakhuis AJ, Hopkins WG. Effect of flavonoids on upper respiratory tract infections and immune function: a systematic review and meta-analysis. Adv Nutr. (2016) 7:488-97. doi: 10.3945/an.115.010538

214. Rane J, Chatterjee A, Ray S. Targeting SARS-CoV-2 spike protein of COVID19 with naturally occurring phytochemicals: an in silico study for drug development. ChemRxiv. (2020). doi: 10.26434/chemrxiv.12094203.v1

215. Adem S, Eyupoglu V, Sarfraz I, Rasul A, Ali M. Identification of potent COVID-19 main protease (Mpro) inhibitors from natural polyphenols: An in silico strategy unveils a hope against CORONA. Preprints. (2020). doi: 10.20944/preprints202003.0333.v1

216. Nguyen TTH, Woo H-J, Kang H-K, Nguyen VD, Kim Y-M, Kim D$\mathrm{W}$, et al. Flavonoid-mediated inhibition of SARS coronavirus 3C-like protease expressed in Pichia pastoris. Biotechnol Lett. (2012) 34:8318. doi: 10.1007/s10529-011-0845-8

217. Jena A, Kanungo N, Nayak V, Chainy GBN, Dandapat J. Catechin and Curcumin interact with corona (2019-nCoV/SARS-CoV2) viral $S$ protein and ACE2 of human cell membrane: insights from Computational study and implication for intervention. Res Square. (2020). doi: 10.21203/rs.3.rs-22057/v1

218. Gennadi G. Genomics-guided tracing of SARS-CoV-2 targets in human cells identifies Vitamin D and Quercetin as candidate medicinal agents for mitigation of the severity of pandemic COVID-19. ChemRxiv. (2020). doi: 10.26434/chemrxiv.12052512.v4

219. Suravajhala R, Parashar A, Malik B, Nagaraj AV, Padmanaban G, Kishor PK, et al. Comparative Docking Studies on Curcumin with COVID-19 Proteins. Preprints. (2020). doi: 10.20944/preprints202005.0439.v2

220. Rocha FAC, de Assis MR. Curcumin as a potential treatment for COVID-19. Phytother Res. (2020) 34:2085-7. doi: 10.1002/ptr.6745

221. Marinella MA. Indomethacin and resveratrol as potential treatment adjuncts for SARS-CoV-2/COVID-19. Int J Clin Pract. (2020) 74:e13535. doi: 10.1111/ijcp.13535

222. Legrand D. Lactoferrin, a key molecule in immune and inflammatory processes. Biochem Cell Biol. (2012) 90:252-68. doi: 10.1139/o11-056

223. Lang J, Yang $N$, Deng $J$, Liu $K$, Yang $P$, Zhang $G$, et al. Inhibition of SARS pseudovirus cell entry by lactoferrin binding to heparan sulfate proteoglycans. PLoS ONE. (2011) 6:e23710. doi: 10.1371/journal.pone.0023710

224. Puddu P, Borghi P, Gessani S, Valenti P, Belardelli F, Seganti L. Antiviral effect of bovine lactoferrin saturated with metal ions on early steps of human immunodeficiency virus type 1 infection. Int J Biochem Cell Biol. (1998) 30:1055-62. doi: 10.1016/S1357-2725(98)00066-1

225. Superti F, Siciliano R, Rega B, Giansanti F, Valenti P, Antonini G. Involvement of bovine lactoferrin metal saturation, sialic acid and protein fragments in the inhibition of rotavirus infection. Biochim et Biophys Acta. (2001) 1528:107-15. doi: 10.1016/S0304-4165(01)00178-7

226. Pietrantoni A, Dofrelli E, Tinari A, Ammendolia MG, Puzelli S, Fabiani C, et al. Bovine lactoferrin inhibits Influenza A virus induced programmed cell death in vitro. BioMetals. (2010) 23:465-75. doi: 10.1007/s10534-010-9323-3
227. Kell DB, Heyden EL, Pretorius E. The biology of lactoferrin, an iron-binding protein that can help defend against viruses and bacteria. Front Immunol. (2020) 11:1221. doi: 10.3389/fimmu.2020.01221

228. Serrano G, Kochergina I, Albors A, Diaz E, Oroval M, Hueso G, et al. Liposomal lactoferrin as potential preventative and cure for COVID-19. Int J Res Health Sci. (2020) 8:8-15. doi: 10.5530/ijrhs.8.1.3

229. Sun J, Ren F, Xiong L, Zhao L, Guo H. Bovine lactoferrin suppresses high-fat diet induced obesity and modulates gut microbiota in C57BL/6J mice. J Funct Foods. (2016) 22:189-200. doi: 10.1016/j.jff.2016. 01.022

230. García OP, Ronquillo D, Caamaño MdC, Camacho M, Long $\mathrm{KZ}$, Rosado JL. Zinc, vitamin A, and vitamin C status are associated with leptin concentrations and obesity in Mexican women: results from a cross-sectional study. Nutr Metab. (2012) 9:59. doi: 10.1186/17437075-9-59

231. Kumar NG, Contaifer D, Madurantakam P, Carbone S, Price ET, Van Tassell B, et al. Dietary bioactive fatty acids as modulators of immune function: implications on human health. Nutrients. (2019) 11:2974. doi: 10.3390/nu11122974

232. Itariu $B K$, Zeyda $M$, Hochbrugger EE, Neuhofer A, Prager $G$, Schindler $K$, et al. Long-chain $n-3$ PUFAs reduce adipose tissue and systemic inflammation in severely obese nondiabetic patients: a randomized controlled trial. Am J Clin Nutr. (2012) 96:1137-49. doi: 10.3945/ajcn.112.037432

233. Flock MR, Rogers CJ, Prabhu KS, Kris-Etherton PM. Immunometabolic role of long-chain omega-3 fatty acids in obesity-induced inflammation. Diabetes Metab Res Rev. (2013) 29:431-45. doi: 10.1002/dmrr.2414

234. Martinez-Fernandez L, Laiglesia LM, Huerta AE, Martinez JA, Moreno-Aliaga MJ. Omega-3 fatty acids and adipose tissue function in obesity and metabolic syndrome. Prostaglandins Other Lipid Mediat. (2015) 121(Pt. A):24-41. doi: 10.1016/j.prostaglandins.2015. 07.003

235. Torrinhas R, Calder P, Lemos G, Waitzberg D. Parenteral fish oil, an adjuvant pharmacotherapy for COVID-19? Nutrition. (2020) 81:110900. doi: 10.1016/j.nut.2020.110900

236. Adili R, Hawley M, Holinstat M. Regulation of platelet function and thrombosis by omega-3 and omega- 6 polyunsaturated fatty acids. Prostaglandins Other Lipid Mediat. (2018) 139:108. doi: 10.1016/j.prostaglandins.2018.09.005

237. Klok FA, Kruip MJHA, van der Meer NJM, Arbous MS, Gommers DAMPJ, Kant KM, et al. Incidence of thrombotic complications in critically ill ICU patients with COVID-19. Thromb Res. (2020) 191:1457. doi: 10.1016/j.thromres.2020.04.013

Conflict of Interest: FU was employed by Reven Pharmaceutcal (Golden, CO).

The remaining authors declare that the research was conducted in the absence of any commercial or financial relationships that could be construed as a potential conflict of interest.

Copyright (C) 2020 Sahin, Orhan, Uckun and Sahin. This is an open-access article distributed under the terms of the Creative Commons Attribution License (CC BY). The use, distribution or reproduction in other forums is permitted, provided the original author(s) and the copyright owner(s) are credited and that the original publication in this journal is cited, in accordance with accepted academic practice. No use, distribution or reproduction is permitted which does not comply with these terms. 